\title{
Xyridaceae of Viruá National Park, Roraima state, Brazil ${ }^{1}$
}

\author{
Nara Furtado de Oliveira Mota ${ }^{2,3,6}$, Lisa M. Campbell ${ }^{4}$, Pedro Lage Viana ${ }^{3}$, Maria das Graças Lapa Wanderley ${ }^{5}$
}

\begin{abstract}
A taxonomic treatment of the Xyridaceae in the Viruá National Park is presented. Located in Roraima state, northern Brazil, the park comprises a mosaic of lowland vegetation types, including forests, wetlands, and one of the largest continuous areas of campinarana in the Brazilian Amazon Basin. Xyridaceae are represented in the park by 20 species in the genera Abolboda and Xyris. Although the four species of Abolboda are widespread, most of the Xyris species (75\%) are endemic to Amazonian open vegetation formations, such as campinaranas and savannas. This study was based on field, herbarium, and scanning electron microscopy research. The taxonomic treatment includes identification keys to the genera and species, morphological descriptions, SEM images of seeds for Xyris species, iconography, geographic distribution and comments on the ecology of the species. The poorly known Xyris connosepala is synonymized in Xyris guianensis.

Key words: Amazon, campinarana, new synonym, seed, white sand vegetation
\end{abstract}

\section{Introduction}

Xyridaceae constitute a group of petaloid monocotyledons classified in Poales (Chase et al. 2000; Soltis et al. 2000; Davis et al. 2004; APG III 2009). The family includes more than 420 accepted species in five genera: Xyris with about 400 species, Abolboda with 23 species, Orectanthe with two species, and Achlyphila and Aratitiyopea with one species each (Kral 1988; Campbell 2004a, 2008; Wanderley 2011; Wanderley et al. 2014). Achlyphila, Aratitiyopea and Orectanthe occur mainly in the highlands of the Guiana Shield, on the remarkable quartzite tepuys of the region (Campbell 2004b, 2005, 2008). Most species of Abolboda occur exclusively in northern South America, especially on the Guiana Shield and to a lesser degree in lowland open vegetation in Amazonian forest, and a few species are found in the Brazilian Cerrado biome, in central Brazil (Kral 1992; Campbell 2005, 2008). Xyris has a wider distribution range, mainly in tropical and subtropical regions of the Americas, Africa, Australia, and Asia, and the remainder are exclusively Neotropical. In the Neotropics, Xyris is widely distributed with two main centers of species richness: the mountains of southeastern Brazil and the Guiana Shield (Kral 1988; Campbell 2004b, 2008). This genus is remarkable in its high level of endemism and species with narrow geographic distribution. Most occur in open areas such as bogs, or rock fields, on sandy soils, that are acidic and poor in nutrients (Kral 1988).

The first comprehensive taxonomic study of Xyridaceae in Brazil was published in the early nineteenth century by Seubert (1855), in the seminal Flora Brasiliensis, in which 28 species of Xyris and six species of Abolboda were treated. Later, in the late nineteenth and early twentieth centuries, Malme published a series of treatments on Xyridaceae (Malme 1896, 1898, 1901, 1912, 1913a, b, 1929), contributing substantially to the taxonomy of the family. Later in that century, botanical exploration in the Guiana Shield, particularly in Venezuela, resulted in an important herbarium collections of Xyridaceae. Subsequent publications by Smith and

\footnotetext{
${ }^{1}$ Part of the first author's PhD dissertation.

${ }^{2}$ Universidade Federal de Minnas Gerais, Inst. Ciências Biológicas, Depto. Botânica, Programa de Pós Graduação em Biologia Vegetal, 31270-901, Belo Horizonte, MG, Brazil.

${ }^{3}$ Museu Paraense Emílio Goeldi, Av. Magalhães Barata, 376, São Braz, 66040-170, Belém, PA, Brazil.

${ }^{4}$ The New York Botanical Garden, 2900 Southern Boulevard, 10458, Bronx, New York, U.S.A.

${ }^{5}$ Instituto de Botânica de São Paulo, Av. Miguel Estéfano, 3687, Água Funda, 04301-012, São Paulo, SP, Brazil.

${ }^{6}$ Author for correspondence: naramota@museu-goeldi.br
} 
Downs (e.g., Smith \& Downs 1954, 1958, 1960, 1965), culminated in a comprehensive monograph of the family in Brazil (Smith \& Downs 1968) that included 115 species of Xyris, 18 Abobolda, one Achlyphila and one Orectanthe. Maguire and collaborators monographed the family for the Guiana Shield, naming two new genera (Maguire 1958; Maguire \& Wurdack 1960; Maguire \& Smith 1964), which was the foundation for Kral's (1988, 1992) important treatments of Xyridaceae in northern South America.

Kral also collaborated with Smith (Kral \& Smith 1980, 1982a, b), and Wanderley (Kral \& Wanderley 1988a, b, 1992, 1995), who is continuously publishing on the taxonomy of the family (e.g., Wanderley 2003, 2010, 2011). Despite the increasing knowledge of Brazilian Xyridaceae, most of the work and published floras of the family have concentrated on southeastern or southern Brazil (e.g., Smith \& Downs 1965; Wanderley 2003, 2011; Mota 2009; Wanderley \& Silva 2009; Mota \& Wanderley 2013, 2014; Silva \& Wanderley 2013). No flora of Xyridaceae has been published for the Brazilian Amazon.

The taxonomic usefulness of seed morphology in Xyridaceae has been noted in the literature (Malmanche 1919; Blomquist 1955; Kral 1966, 1988; Rudall \& Sajo 1999). However, few floras and taxonomic treatments around the world present these characters combined with macromorphology (e.g., Doust \& Conn 1994; Lock 1998; Phonsena et al. 2012). In Eriocaulaceae, the putative sister group of Xyridaceae (Bouchenak-Khelladi et al. 2014), seed coat ornamentation has been demonstrated to have taxonomic value at several ranks allowing distinction genera and some subgenera (Zona et al. 2012; Barreto et al. 2013).

Based mainly on macromorphological and seed ornamentation characters, this work provides a taxonomic treatment of Xyridaceae in Viruá National Park (Roraima state in northern Brazil). Detailed morphological descriptions and characterization of seed morphology as viewed under SEM are provided for Xyris. An identification key to the genera and species, comments on the ecology, morphology, and distribution for all species are also provided here.

\section{Methods}

Study site

Viruá National Park (VNP) is situated in Roraima state, northern Brazil, and is delimited by the coordinates: $0^{\circ} 56^{\prime} \mathrm{N}, 61^{\circ} 09^{\prime} \mathrm{W}$ (south), $1^{\circ} 43^{\prime} \mathrm{N}$, $6108^{\prime} \mathrm{W}$ (north), $1^{\circ} 17^{\prime} \mathrm{N}, 60^{\circ} 58^{\prime} \mathrm{W}$ (east), $11^{\prime} 7^{\prime} \mathrm{N}$, $61^{\circ} 18^{\prime} \mathrm{W}$ (west), at the northern border of the Pantanal Setentrional (Santos et al. 1993; Rossetti et al. 2012a, b; Zani at al. 2012; Zani \& Rossetti 2012) - a depression between the Negro and Branco river basins. The VNP has a total area of 227,000 hectares and is bounded by the rivers Barauana on the east, Branco on the west, and Anauá, which constitutes its southern limit. According to Rossetti et al. (2012a, b), the topography of VNP is formed by the Viruá Megafan, an uncommon geological feature, the result of alluvial sediment deposition from fluvial channels.

The topography is predominantly low elevation (45-60 m) but reachs elevations of $350 \mathrm{~m}$, such as the Serra do Preto $\left(1^{\circ} 13^{\prime} 07^{\prime \prime} \mathrm{N}, 61^{\circ} 08^{\prime} 53^{\prime \prime} \mathrm{W}\right)$. The area is characterized by sandy, nutrient poor and poorly-drained soils, that are developed on an extensive sedimentary lowland plain, derived from quartzite sands from the Içá geological formation (Rossetti et al. 2012b; ICMBio 2014).

The vegetation is an extensive mosaic of complex, seasonally flooded forested and nonforested systems (Mendonça 2011) (Fig. 1 a-e). The phytophysiognomies in the area are classified as terra firme, várzea, or igapó forests; Mauritia flexuosa L.f. dominated communities (buritizais); arborescent campinarana; grassy campinarana (or campina); and aquatic vegetation in bodies of water (Damasco et al. 2013; ICMBio 2014). The campinaranas in the area occur in a wide system of wetlands that grow on white sand soils, and are seasonally flooded (Lisboa 1975; Prance 1975; ICMBio 2014; Mendonça et al. 2014). This vegetation type is known to be rich in graminoid monocots, especially the families Cyperaceae, Eriocualaceae, Rapateaceae, and Xyridaceae (Pires \& Prance 1985). The campinaranas of Viruá National Park are one of the largest continuous areas of this vegetation type in the Brazilian Amazon (Damasco et al. 2013; ICMBio 2014; Mendonça et al. 2014).

According to Köppen's classification map (Alvares et al. 2013), the climate is monsoontropical (Am). The monthly temperatures ranges from $20^{\circ}-38^{\circ} \mathrm{C}$, the annual average is $24^{\circ} \mathrm{C}$ (Rossetti et al. 2012b). The average annual rainfall is about $2000 \mathrm{~mm}$, the same for the state.

Fieldwork

Three field expeditions were conducted in dry and wet season (Jan 2009, Sep and Nov 
2011), totaling 39 days of fieldwork. Sampling was concentrated in the open areas of the park, such as campinaranas and aquatic vegetation. Herbarium specimens were deposited in BHCB, INPA, NY, and SP (acronyms follow Thiers 2014).

\section{Taxonomic treatment}

Species were identified using protologues and other pertinent literature (Seubert 1855; Steudel 1855; Nilsson 1892; Malme 1912, 1913a, b; Smith \& Downs 1968; Steyermark 1984; Kral 1988, 1992, 2005; Kral \& Jansen-Jacobs 1998) and through study of specimens, including types, from $\mathrm{B}, \mathrm{BHCB}$, INPA, K, MG, MO, NY, SP, SPF, and US, as well as on-line images from BRG, BRIT (VDB), P, S, and U (acronyms follow Thiers 2014). All specimens from the study area deposited in INPA were studied (about $50 \%$ of the specimens examined). Species descriptions, illustrations and photographs were prepared from specimens collected in the study area, and include at least the apex and base of leaves, spike, and lateral sepals.

Morphological terminology follows Kral (1988, 1992), except for the terms "dorsal area" and "scape", replaced here by "macula" and "peduncle", respectively. Changes were also made in Kral's (1988) terminology for seed ornamentation: "stria" instead of "rib", "reticulate" instead of "anastomosing ribs" and "moniliform" instead of "pebbled". Data on geographic distribution were gathered from $\operatorname{Kral}(1988,1992)$, Campbell (2005) and Wanderley et al. (2014).

\section{Scanning electron microscopy (SEM)}

Seeds of Xyris species were taken from dried specimens and coated with gold palladium in a Hummer 6.2 sputtering system (Anatech, Union City, CA, U.S.A). Observations were made with a JEOL JSM-5410LV SEM (JEOL, Tokyo, Japan) at $10 \mathrm{kV}$ and digital images were acquired using Orion software (JEOL, Tokyo, Japan). Only seeds that appeared fully formed were measured.

\section{Results and discussion}

\section{Flora}

A total of 21 taxa, including four Abolboda and 16 Xyris species, and one variety, X. uleana var. angustifolia Lanj., were recorded in the study area. This represents $60 \%$ of Xyridaceae species reported for the Roraima state flora (Wanderley et al. 2014).

The Abolboda species observed are mostly widely distributed at low to mid elevation in white sand formations of the Brazilian Amazon and the Guiana Shield. Abolboda americana also occurs in the coastal restingas of Nertheastern Brasil and $A$. pulchella extends to the Espinhaço Range and the savannas of Central Brazil.

Thirty percent of Xyris species known to occur in Brazilian Amazonia (Wanderley et al. 2014) were found in the VNP. Ten of these were restrict to Amazonian ecosystems (X. cryptantha Maguire \& L.B.Sm., X. dilatatiscapa Kral \& Jans.Jac., $X$. guianensis Steud., $X$. involucrata Nees, $X$. malmeana L.B.Sm., X. mima L.B.Sm. \& Downs, $X$. subglabrata Malme, $X$. subuniflora Malme, $X$. surinamensis Spreng., X. uleana var. angustifolia Lanj.) (Kral 1988; Wanderley et al. 2014) and five are widespread in South America (Xyris fallax Malme, X. jupicai Rich., X. macrocephala Vahl, $X$. paraensis Poepp. ex Kunth and $X$. savanensis Miq.). One species (referred to as Xyris sp.1), belonging to the $X$. paraensis complex, could not be identified and probably represents a new taxon. A comprehensive study of types of all names related to the $X$. paraensis complex is necessary to confirm this hypothesis.

Xyris dilatatiscapa was previously known only from Guyana (Kral \& Jansen-Jacobs 1998), and $X$. cryptantha, X. fallax, X. malmeana, X. mima, X. paraenses, X. subglabrata and X. uleana var. angustifolia are known from Roraima only by collections from the study study area (see Wanderley et al. 2014).

All of the Xyridaceae were documented in open formations (campinaranas or campinas). During the rainy season, it is common to find plants of Xyris and Abolboda partially or completely submerged in the lakes and streams (or igarapés) thoughout the campinaranas of the VNP. None of the taxa recorded in the VNP are formally considered threatened (MMA 2014; Wanderley et al. 2014). Most of Amazonian Xyris species are classified as Data Deficient according to IUCN (2012) criteria, due to the scarcity of information available for that family in the Brazilian Amazon.

Shape and ornamentation of seeds of Xyris species

Seeds of Xyris species occurring in the VNP are $0.3-1.5 \mathrm{~mm}$ long, ovoid, obovoid, or ellipsoid, striate, with an apiculate apex (Fig. 3a-q). Viewed using SEM, the striae were thickened (X. cryptantha, $X$. subuniflora and X. uleana var. uleana, Fig. 3a, m $\& \mathrm{p})$ or not $(X$. dilatatiscapa and $X$. fallax, Fig. $3 \mathrm{~b}$ $\&$ c), smooth (X. subglabrata, Fig. 31), sinuous ( $X$. guianensis, Fig. 3d), or moniliform (X. mima, Fig. 

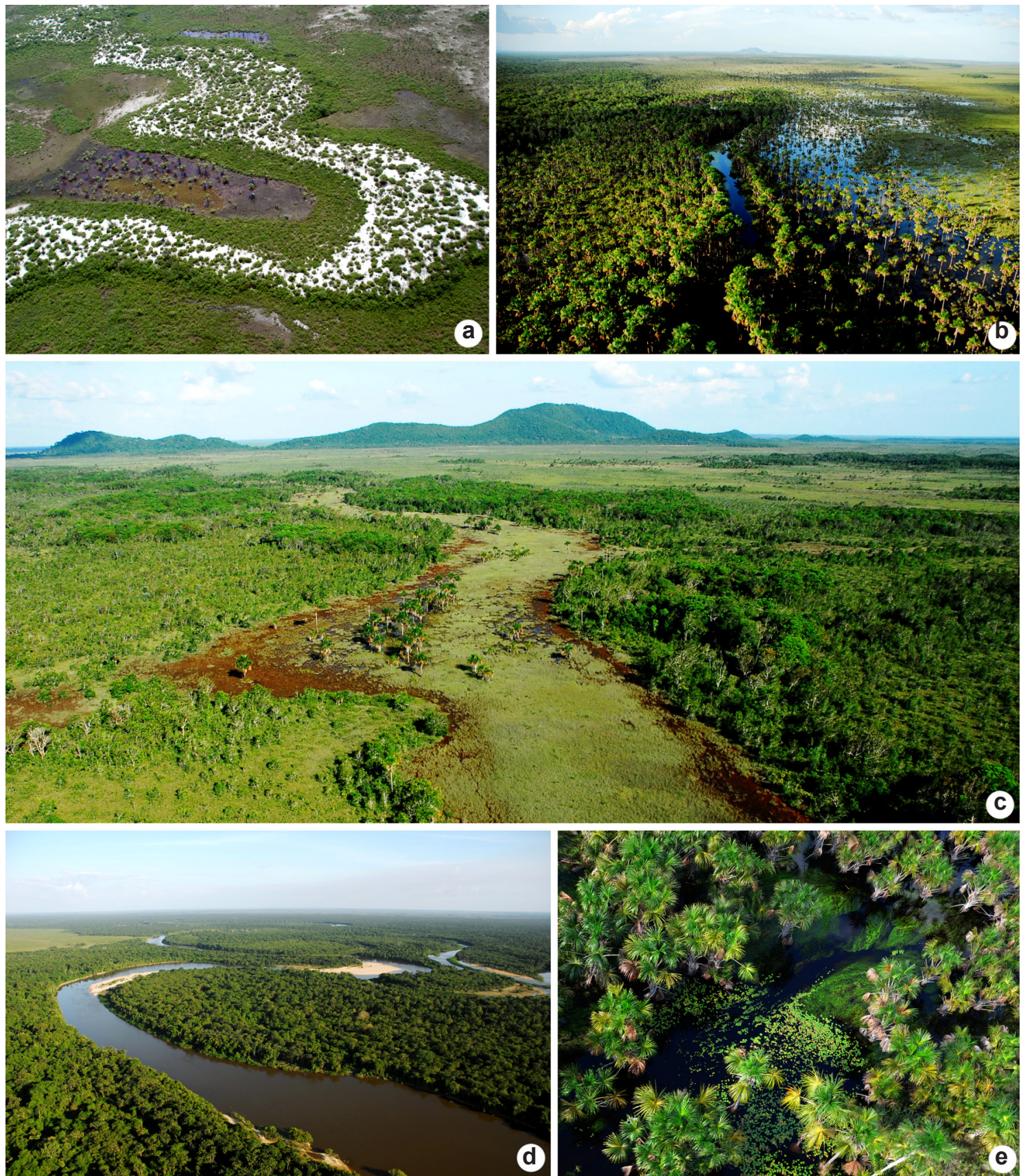

Figure 1 - Aerial photographs of vegetation types in Viruá National Park (VNP) - a. Open vegetation of a mosaic of campinaranas covering the Viruá Megafan; b. Mauritia flexuosa dominated communities (buritizais) along a tributary of the Anauá, southern sector of VNP; c. A paleochannel dissecting a mosaic of campinaranas on the Viruá Megafan. A view of Serra do Preto is in the background; d. Várzea forest with small sandy beaches along the Anauá river, southern limit of VNP; e. Aquatic vegetation in the small tributary "igarapé Preto". Photographs by: a. Bruno Mendonça; b-d. Antônio Iaccovazo; e. Rogério Gribel. Courtesy of ICMBio.

3i). Sometimes more than one form of stria was observed on the same seed, as in X. paraensis (Fig. $3 j$ ). The region between the striae can be clearly visible, as in $X$. jupicai and X. macrocephala (Fig. 3f-g), or not, as in $X$. fallax (Fig. 3c). Some species have cross-lines (transverse striae) frequently 
forming a reticulate pattern of ornamentation (striae and cross-lines evenly distributed), as seen in $X$. dilatatiscapa (Fig. $3 b$ ). The ornamentation of the seed coat was very useful in distinguishing morphologically close species, such as Xyris mima and Xyris paraensis (see comments under
X. mima) and in synonymizing X. connosepala in $X$. guianensis (see comments under $X$. guianensis). The salient seed characters of Xyris species are summarized in Table 1.

\section{Taxonomic treatment}

\section{Key to the genera of Xyridaceae occurring in the Viruá National Park}

1. Leaves polystichously arranged; petals blue, lilac, or purple, rarely white; staminodia absent; style with three basal appendages 1. Abolboda

1'. Leaves distichously arranged, less commonly spiralate; petals yellow; staminodia present; style not appendiculate 2. Xyris

1. Abolboda Humb. in Humb. \& Bonpl., Pl. Aequinoct. 2: 109. 1809.

Perennials herbs, terrestrial. Plants solitary or clump-forming. Roots coarse, spongy, often with a sheath of sand-binding of hairs. Base sub-bulbous to bulbous, fibrous or not, without mucilage. Stems developed into a caudex to very reduced. Leaves dorsiventral, polystichous, in a dense or loose rosette, dimorphic or not; sheath broadly clasping at the base, smooth, papilose, verrucous, or rugose, margins glabrous, ligule absent; lamina flattened, smooth, papillose, verrucous, or rugose, margins usually glabrous. Inflorescence subtended by a basal peduncular bract, usually with 1 or 2 pairs of subopposite, chlorophyllous peduncular bracts; peduncle terete to sub-terete, not twisted, glabrous, smooth, ecostate. Spike 1-multi-flowered, elongate, sometimes compressed, or turbinate; sterile and fertile bracts similar, stiff, mostly green or tinged with purple, persistent. Sepals 2-3, dimorphic; dorsal sepal translucent, cartilaginous, deciduous, sometimes very reduced or not present; lateral sepals imbricate, navicular, asymmetric, free, shorter or larger than the bracts, not keeled, often carinate, numerous viens visible, firm, glabrous. Corolla polysymmetric or monosymmetric, salverform or porrect; petals 3 , not unguiculate, membranaceous, blue, lilac, or purple, rarely white, connate. Staminodia not present; stamens 3 , epipetalous; filaments flattened, white or concolorous with the corolla; anthers dorsifixed, extrorse, dehiscing by vertical slits, connective apex sunken. Style sunken or not, triquetrous, distally 3-branched, with 3 unequal, vascularized, delicate appendages, appendages dorsal, linear, unequal, pendulous; ovary sessile, 3-loculed, placentation axial. Capsule several-many-seeded. Seeds obovoid to rounded or nearly prismatic, asymmetric, with pronounced longitudinal striations, and finer cross-lines.

\section{Key to the species of Abolboda occurring in Viruá National Park, Roraima, Brazil}

1. Peduncle very reduced and the flowers appearing sessile, or if present without bracts along the axis; leaves linear, $<1 \mathrm{~mm}$ wide .

1'. Peduncle $>15 \mathrm{~cm}$ long, with one or more pairs of subopposite bracts; leaves subulate or lanceolate, $>$ $1 \mathrm{~mm}$ wide.

2. Spikes pedunculate, turbinate, $2-5$-flowered .

1.1. Abolboda americana

2'. Spikes nearly sessile (peduncle $<0.6 \mathrm{~mm}$ ), $1-2$-flowered 1.2. Abolboda killipii

3. Spikes ellipsoid, compressed, 9-13-flowered 1.3. Abolboda macrostachya

3'. Spikes obovoid, turbinate, 2-5-flowered 1.4. Abolboda pulchella

1.1 Abolboda americana (Aubl.) Lanj., Meded. Bot. Mus. Herb. Rijsk. Univ. Utrecht 41: 492. 1937.

Figs. 2a, 7a

Plants cespitose. Roots ca. $1 \mathrm{~mm}$ wide, covered with sand binding trichomes. Stem very reduced.
Leaves dimorphic; main leaves $0.9-8.2 \times 0.05-0.1$ $\mathrm{cm}$, linear, smooth, dull to glossy, apex acute, rounded, or apiculate. Basal peduncular bracts $0.2-0.6 \mathrm{~cm}$ long; peduncle $1.5-6.7 \times 0.04-0.05 \mathrm{~cm}$, usually longer than the leaves, terete, smooth; peduncular bracts absent, 
Spike turbinate, obconical, or ellipsoid, 2-5-flowered; sterile bracts (1) 2 or 3; fertile bracts $0.5-0.7 \mathrm{~cm}$ long, navicualr, carinate, tawny to hyaline, apex mucronate to awned. Sepals 2-3, lateral sepals ca. $5.5 \times 1.3 \mathrm{~mm}$, elliptic in profile, weakly inequilateral, navicular, chartaceous, except for the firm keel. Petals $2.3 \mathrm{~mm}$, lobe ca. $4 \mathrm{~mm}$ wide, blue, lilac or white. Anthers 0.8-0.9 mm long. Style $7 \mathrm{~mm}$ long, with 3 appendeges inserted $1 \mathrm{~mm}$ from the ovary, reflexed portion of appendages $0.4,0.4,0.8 \mathrm{~mm}$ long; stigma ca. $2.5 \mathrm{~mm}$ wide. Capsule Capsule ca. $1.2 \mathrm{~mm}$ long, apex smooth. Seeds $0.5-0.7 \times 0.6-0.8 \mathrm{~mm}$, asymmetric, obovoid, or subglobose, longitudinally striated, cross-lines irregularly distributed.

\section{Morphological comments}

As with Abolboda pulchella and A. killipii, the inflorescences of $A$. americana are fewflowered (never more than 5 flowers per spike), but the species can be distinguished from the other species by its usually turbinate spike, mainly patent leaves and the more delicate plants. The peduncles are shorter than those of $A$. pulchella (1.5-6.7 cm long vs. $26-35 \mathrm{~cm}$ in $A$. puclella), sometimes shorter than the $1^{\circ}$ leaves, but never inconspicuous, as in A. killipii. Sterile specimens of $A$. americana could be confused with $A$. killipii, however the latter is more densely caespitose.

\section{Distribution and habitat}

Abolboda americana occurs in low elevation sandy savannas in French Guiana, across the Guiana Shield to southeastern Colombia, and in Amazonian and central Brazil. The species is widespread in Brazil, occurring in Amapá, Amazonas, Bahia, Pará, Paraíba, Rondônia, and Roraima states. In VNP, A. americana is widespread throughout the campinaranas, being particularly common in peaty bogs, where it forms dense mats. During the rainy season, it was observed partially submersed with only the spikes exposed.

Representative material examined: BRAZIL. Roraima: Município Caracaraí, Parque Nacional do Viruá, Estrada Perdida, 28.XI.2006, F.A. Carvalho and M. Roache 938 (INPA); estrada perdida, 12.X.2011, N.F.O. Mota et al. 2343 (BHCB, INPA); grade PPBio, 17.X.2011, N.F.O. Mota et al. 2406 (BHCB, INPA).

1.2 Abolboda macrostachya Spruce ex Malme, Bih. Kongl. Svenska Vetensk.-Akad. Handl. 26, Afd. 3(19): 15. 1901.

Fig.s 2b, 7b,c

Plants solitary to cespitose. Roots ca. $3 \mathrm{~mm}$ wide, covered with sand binding trichomes. Caudex \pm vertical, or horizontal. Leaves monomorphic; main leaves $9-26 \times 0.3-0.7 \mathrm{~cm}$, linear to lanceolate, smooth, dull, apex pungent. Basal peduncular bracts $1.7-3.2 \mathrm{~cm}$ long; peduncle $35-$ $58 \times 0.2-0.3 \mathrm{~cm}$, usually longer than the leaves, terete to sub-terete, smooth; peduncular bracts in 2 pairs, 2.3-2.5 $\mathrm{mm}$ long, green, sometimes tinged purple, margin hyaline, apex acute. Spike ellipsoid, compressed, 9-13-flowered; sterile bracts absent; fertile bracts $2.5-2.8 \mathrm{~cm}$ long, broadly navicular, carinate, green to olive-green, or tinged purple, apex mucronate. Sepals 2, laterla sepals $13-14 \times 2.7-3 \mathrm{~mm}$, elliptic in outline, apex erose, equilateral to weakly inequilateral, navicular, sclerous. Petals $25-30 \mathrm{~mm}$ long, lobe 10-15 mm wide, (white) blue, lilac. Anthers 3-4 mm long. Style 15-25 $\mathrm{mm}$ long, with 3 appendages inserted $0.6 \mathrm{~mm}$ from the ovary, reflexed portion of appendages $3,3.5,3.5 \mathrm{~mm}$ long; stigma ca. $5 \mathrm{~mm}$ wide. Capsule Capsule ca. $3 \mathrm{~mm}$ long, apex smooth. Seeds 0.9-1 $\times$ 0.9-1 mm, asymmetric, flattened on one surface, longitudinally striated, cross-lines.

\section{Morphological comments}

Abolboda macrostachya is the most conspicuous species of the genus in the VNP, characterized by robust rhizomes, leaves to 26 $\mathrm{cm}$ long, and spikes 3-4.5 cm long, with bluish corollas and several simultaneous flowers. A single specimen with unusual white flowers was collected (Mota 2425). The plants are usually caespitose, but a few solitary individuals were observed in the field.

\section{Distribution and habitat}

Abolboda macrostachya occurs at mid to high elevations in Amazonian and Central Brazil, southeastern Colombia and southwestern Venezuela. In Brazil the species is known from Amazonas, Mato Grosso, and Roraima states. Abolboda macrostachya is was the most common species of Abolboda encountered in VNP. In the park populations of this species grow in dense graminoid formations in the bogs of campinaranas.

Representative material examined: Grade PPBio L3N4, 17.XII.2011, J. Lins et al. 36 (INPA); Estrada Perdida, campina próxima a guarita do parque, 22.IX.2011, N.F.O Mota et al. 2304 (BHCB, SP); campina cerca de $1 \mathrm{~km}$ depois da segunda bueira na Estrada Perdida, 23.IX.2011, N.F.O Mota et al. 2319 (BHCB, SP). 
1.3 Abolboda killipii Lasser, Bol. Soc. Venez. Ci. Nat. 9 (59): 178. 1944.

Figs $2 \mathrm{c}, 7 \mathrm{~d}$

Plants cespitose. Roots $0.5-0.8 \mathrm{~mm}$ wide, sparsely covered with sand-binding trichomes. Stem very reduced. Leaves dimorphic; main leaves $0.6-1 \times 0.04-0.05 \mathrm{~cm}$, linear, smooth to irregularly papilose, apex bluntly rounded, minutely apiculate on the adaxial surface. Basal peduncular bracts not observed; peduncle $<0.6 \mathrm{~cm}$ long, shorter than the leaves, terete, smooth; peduncular bracts absent. Spike turbinate, 1-2-flowered; sterile bracts absent; fertile bracts $0.7-0.8 \mathrm{~cm}$ long, not navicular, not carinate, olive-green, paler at the base, margin hyaline, apex acute, mucronate. Sepals 2, laterla sepals 5.5-7.5 $\times 0.7$ $\mathrm{mm}$, weakly falcate in profile, equilateral to weakly inequilateral, navicular, chartaceous. Petals 10-14 $\mathrm{mm}$ long, lobe ca. $4 \mathrm{~mm}$ wide, blue, lilac. Anthers $1 \mathrm{~mm}$ long. Style $6.5 \mathrm{~mm}$ long, with 2 appendeges inserted 0.5 and $1.8 \mathrm{~mm}$ from the ovary, reflexed portion of appendages $0.4,0.6 \mathrm{~mm}$ long; stigma ca. $2 \mathrm{~mm}$ wide. Capsule Capsule ca. $2 \mathrm{~mm}$ long, apex rounded. Seeds ca. $0.7 \times 0.7-0.8 \mathrm{~mm}$, obovoid, longitudinally striated, cross-lines.

\section{Morphological comments}

This diminutive species can be easily distinguished from other congeners in the VNP by the nearly sessile spikes. The inflorescences of the other three species of Abolboda found in the study area are borne on elongate peduncles. Plants of A. killipii form dense, compact green cushions on the sand.

\section{Distribution and habitat}

Abolboda killipii is known from Amazonian Brazil (Amazonas and Roraima states), southwestern Venezuela, Guyana, and Suriname, and is reported from southeastern Colombia (Cardenas-López et al. 2007). The leaves are densely compact near the substrate, forming cushions. In the study area $A$. killipii was found growing on exposed white sand campinaranas that are seasonally flooded, amongst Xyris subuniflora, X. mima, Eriocaulaceae, Lentibulariaceae, and some small Rubiaceae.

Representative material examined: Estrada Perdida, após a $1^{\mathrm{a}}$ bueira, 22.VII.2010, A. Melo et al. 406 (INPA); Estrada Perdida, 22.VII.2010, D. Cavalcanti et al. 200 (INPA); ca. $1 \mathrm{~km}$ após $2^{\text {a }}$. bueira na Estrada Perdida, 23.IX.2011, N.F.O Mota \& P.L.Viana 2325 (BHCB, SP).

1.4 Abolboda pulchella Humb. in Humb. \& Bonpl., Pl. Aequinoct. 2: 110, pl. 114. 1809. Figs 2d, 7e

Plants solitary to cespitose. Roots ca. $4 \mathrm{~mm}$ wide, covered with sand binding trichomes. Caudex \pm vertical. Leaves dimorphic; main leaves 3.5-8.8 $\times 3 \mathrm{~cm}$, linear-lanceolate, smooth, dull, apex pungent. Basal peduncular bracts 2.7-2.8 cm long; peduncle $26-35 \times 0.1-0.3 \mathrm{~cm}$, usually subequal to the leaves, terete, smooth; peduncular bracts in 1 pair, ca. $2.8 \mathrm{~mm}$ long, pale olive-green to khakigreen, margin hyaline, apex acute. Spike obovoid, turbinate, 2-5-flowered; sterile bracts absent; fertile bracts $0.4-0.8 \mathrm{~cm}$ long, broadly navicular, not carinate, green to olive-green, margins brown, apex mucronate. Sepals 2, laterla sepals 4.8-5.2 $\times 0.6 \mathrm{~mm}$, rounded, elliptic in profile, weakly inequilateral, broadly navicular, sclerous. Petals 13-16 mm long, lobe ca. $5 \mathrm{~mm}$ wide, blue, purple, white. Anthers $0.7-0.9 \mathrm{~mm}$ long. Style ca. $7.5 \mathrm{~mm}$ long, with 3 appendeges inserted $0.8 \mathrm{~mm}$ from the ovary, reflexed portion of appendages $0.4,0.5,1$ $\mathrm{mm}$ long; stigma ca. $3 \mathrm{~mm}$ wide. Capsule Capsule ca. $4 \mathrm{~mm}$ long, apically umbilicate. Seeds $0.5-0.7$ $\times 0.5-0.8 \mathrm{~mm}$, broadly obovoid, longitudinally striated, cross-lines.

\section{Morphological comments}

Abolboda pulchella is a morphologically variable species that among the species in the VNP, can superficially resemble $A$. americana because both species have few-flowered, small spikes, (to 1.2 and $0.6 \mathrm{~cm}$, respectively). Abolboda pulchella, however, can be distinguished by longer peduncles with a single one pair of peduncular bracts and erect leaves, that are never patent, as in A. americana.

\section{Distribution and habitat}

As presently circumscribed, Abolboda pulchella has the most extensive distribution of species in the genus, occurring in grasslands at low to moderate elevation in Suriname, across the Guyana Shield to southeastern Colombia, and in Amazonian and central Brazil. The species is widespread in Brazil, occurring in Amapá, Amazonas, Bahia, Distrito Federal, Pará, Rondônia, and Roraima states. It occurs from Suriname, across the Guiana Shield to southeastern Colombia, and south to $23^{\circ}$ south in Brazil (Campbell 2005). In Brazil it is known from the states Bahia, Espírito Santo, Goiás, Mato Grosso, Mato Grosso do Sul, Minas Gerais, Pará, Piauí, Roraima, São Paulo, Tocantins, and the Distrito Federal. Populations of Abolboda pulchella usually consist of a few scattered individuals and in the VPN the species appears to be rare. The few individuals observed were along the margins of streams (igarapés), amongst dense graminoid vegetation. 




Figure 2 - Species of Abolboda in Viruá National Park, Brazil. a. Abolboda americana (N.F.O. Mota et al. 2343); b. A. macrostachya (C.T. Pedrollo et al. 143); c. A. killipii (N.F.O Mota and P.L. Viana 2325); d. A. pulchella, note the dimorphic leaves (S.M. Costa and T.D.M. Barbosa 921). 
Representative material examined: campina ca. $1 \mathrm{~km}$ depois da $2^{\mathrm{a}}$. bueira na Estrada Perdida, 23.IX.2011, N.F.O Mota and P.L.Viana 2322 (BHCB, SP); 20.III.2010, S.M. Costa \& T.D.M. Barbosa 921 (INPA); 24.VII.2010, T.D.M. Barbosa \& S.M. Costa 1313 (INPA).

2. Xyris Gronov. ex L. Species Plantarum 1: 42. 1753.

Annual or perennial herbs, terrestrial, rare aquatics. Plants solitary or clump-forming. Roots fibrous, not spongy, without a sheath of sandbinding of hairs. Base of the plant flattened, subbulbous to bulbous, fibrous or not, sometimes with mucilage. Rhizome present or not, usually with short internodes. Leaves isobilateral, usually distichous or rare spiral, erect to spreading, twisted or not, not dimorphic; sheaths dilated or narrow at the base, smooth, papilose, verrucous, or rugose, margins glabrous to long ciliate, ligule present or not; lamina flattened to terete, smooth, papillose, verrucous, or rugose, margins glabrous to ciliate. Inflorescence subtended by a basal peduncular bract (spathe), bracts along the peduncle absent; peduncle terete, triquetrous to compressed, twisted or not, glabrous to ciliate, smooth, papillose, verrucous or rugose, ecostate to multicostate, rarely winged. Spike 1multi-flowered, ovoid, obovoid, ellipsoid, oblong, cylindrical, hemispherical to globous; sterile bracts 2-many, the lower ones different or similar to the inner bracts, keeled or not, sometimes with one macula on dorsal surface, margins differentiated or not, entire to lacerate, glabrous to ciliate; fertile bracts in generally alike to very distinct of the sterile bracts, keeled or not, macula present or not, margins differentiated or not, entire to lacerate, glabrous to ciliate. Sepals 3, dimorphic; dorsal sepal cucullate, membranous, deciduous; lateral sepals imbricate, navicular, symmetric to asymmetric, free to connate, shorter or larger than the bracts, keel glabrous to ciliate, entire to lacerate. Corolla usually polysymmetric, tubular; petals 3, unguiculate, membranaceous, yellow or white, free to connate. Staminodia 3, alternate with the petals, branched, glabrous to pubescent, hairs long-penicillate; stamens 3 , epipetalous; filaments flattened, concolorous with the corolla; anthers basifixed, extrorse, dehiscing by vertical slits. Style filiform, distally 3-branched, lateral appendages absent; ovary usually sessile, 1- or 3-loculed, or imperfectly 3-loculed, placentation parietal, central, basal, suprabasal or axial. Capsule usually many-seeded. Seeds ovoid, obovoid, cylindrical to ellipsoid, rarely angular, with pronounced longitudinal striation, with or without cross-lines, apex usually apiculate.

\section{Key to the species of Xyris in the Viruá National Park}

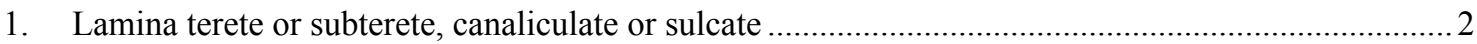

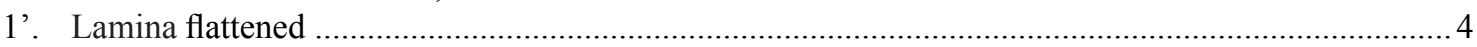

2. Spathe longer than the leaves, peduncle dilated in the $1-3.3 \mathrm{~cm}$ of the distal portion.

2'. Spathe shorter than the leaves, peduncle not dilated at the apex

3. Spike 4-6-flowered; the lower sterile bracts distinctly longer than the fertile bracts; axial placentation

2.1. Xyris cryptantha

3'. Spike 10-15-flowered; the lower sterile bracts about $1 / 2$ the length of the fertile bracts; central placentation

2.12. Xyris subglabrata

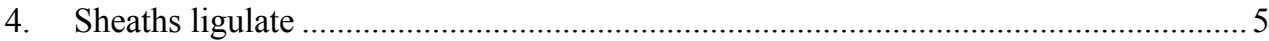

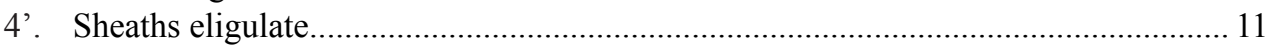

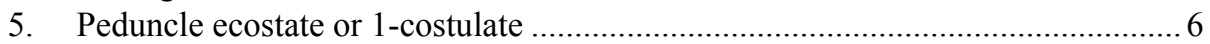

5'. Peduncle 1- or 2-costate or multicostulate ............................................................ 8

6. Lamina surface papillose to densely rugose; spike 10-35-flowered

2.11. Xyris savanensis

6'. Lamina surface smooth; spike with 3 or less flowers

7. Lateral sepals exserted, keeled; central placentation.

2.4. Xyris guianensis

7'. Lateral sepals incluse, not keeled; basal placentation

2.13. Xyris subuniflora

8. Sterile bracts 4; parietal placentation ..... 9

8'. Sterile bracts 10-20; basal placentation 10 
9. Leaf sheath margins glabrous; seeds $0.5-0.8 \mathrm{~mm}$ long

2.6. Xyris jupicai

9'. Leaf sheath margins ciliate; seeds $1.3-1.5 \mathrm{~mm}$ long

10. Lamina surface densely transversely rugose; seeds $\geq 1 \mathrm{~mm}$, apex acute with a coma of bristles ..

10'. Lamina surface smooth; seeds $0.3-0.4 \mathrm{~mm}$ long, apex apiculate

2.15. Xyris uleana var. angustifolia

11. Peduncle ancipital, characteristically two winged

11'. Peduncle flattened, subterete, terete or triquetrous, not winged

12. Lamina margins densely ciliate; peduncles longer than $38-60 \mathrm{~cm}$

2.5. Xyris involucrata

12'. Lamina margins glabrous; peduncles smaller than $26.2 \mathrm{~cm}$ long

2.16. Xyris uleana var. uleana

13. Leaf sheath margins ciliate.

13'. Leaf sheath margins glabrous

14. Peduncle terete to subterete, filiform, 3 or 4-costate; sterile bracts 4

2.8. Xyris malmeana

14'. Peduncle flattened, 2-costate; sterile bracts 18-22.

2.14. Xyris surinamensis

15. Peduncle longer than $100 \mathrm{~cm}$; sterile bracts $16-22$; seeds reticulate .......

2.7. Xyris macrocephala

15'. Peduncle $\geq 32 \mathrm{~cm}$; sterile bracts 4 ; seeds striate

.16

16. Spike ovoid; keel of lateral sepals glabrous and slightly lacerate; seed with monilliform and smooth striae

2.10. Xyris paraensis

16'. Spike cylindrical; keel of lateral sepal evenly ciliate; seed with smooth striae.

2.17. Xyris sp.1

2.1 Xyris cryptantha Maguire \& L.B.Sm, Mem. New York Bot. Gard. 10(5): 16, t.2 a-e. 1964.

Figs. 3a, 4a-d, $7 \mathrm{f}$

Perennial, terrestrial, short living, clumpforming. Base of the plant sub-bulbous, fibrous, without mucilage. Leaves $7.9-19 \mathrm{~cm}$ long, spiral, erect, not twisted; sheaths $1 / 4-1 / 10$ the leaf length, gradually dilating toward the base, smooth, with prominent nerves, castaneous, margins not scarious, floccose-ciliate, eligulate; lamina $5.9-15.2 \mathrm{~cm} \times 0.5-0.7 \mathrm{~mm}$, terete to subterete, smooth and pale-puncticulate, nerves not evident at the base, margins undifferentiated, glabrous, apex subulate to conic, usually incurved. Spathe shorter than the leaves. Peduncle $11.5-30 \mathrm{~cm}$ long, $0.4-0.5 \mathrm{~mm}$ wide, filiform, terete, without distal dilatation, not twisted to sligthly twisted, glabrous, smooth, densely pale-puncticulate, ecostate. Spike 4-6-flowered, 6-11 × 2-4 mm, oblanlaceolate to obovoid, reddish castaneous. Sterile bracts 4-6, the lower ones distinctly longer than the fertile bracts; the uppermost oblong to oblong-pandurate, slightly keeled at the apex, maculate, margins scarious, glabrous, apex keeled to cucullate. Fertile bracts $5.4-7.3 \times 1.3-1.6 \mathrm{~mm}$, oblong to oblonglanceolate, navicular, margins glabrous, scarious, entire to lacerate, pale to reddish, apex cucullate; macula along the distal $1 / 2$ of the fertile bract, ovallanceolate, greenish and becoming castaneuous with age, pale-puncticulate. Lateral sepals 4.5-6 $\mathrm{mm}$, linear-lanceolate, slightly asymmetric, free, shorter than the bracts, keel glabrous to slightly ciliolate at the tip; corolla lobes obovate to broadly obovate; staminodia densely long-penicillate, branches not flat; stamens $2.5 \mathrm{~mm}$ long; anther 1.5 $\mathrm{mm}$ long, sagittate; style $7.5 \mathrm{~mm}$ long, branches $3 \mathrm{~mm}$ long; ovary $2.2 \mathrm{~mm}$ long, trilocular, axial placentation. Capsule $0.5 \mathrm{~mm}$ long, ellipsoid. Seeds $0.4-0.5 \times 0.2-0.3 \mathrm{~mm}$, ovoid to ellipsoid, reddish to castaneous, apiculate apex; striae 5-6 per 100 $\mu \mathrm{m}$ of seed width in the midle portion, slightly prominent, straight, slightly sinuous, with thin cross-lines, not reticulate.

\section{Distribution and habitat}

According to Kral (1988), X. cryptantha occurs in lowland, sandy savannas of southeastern Colombia, and Venezuela and disjunct on Serra do 
Aracá, Amazonas state, Brazil. Viruá National Park is located between Serra do Aracá and Amazonas state in Venezuela; this report of $X$. cryptantha is the first for Roraima state. The species was collected in seasonally flooded campinaranas with sandy soils. Representative material examined: Campina, estrada para Serra do Preto, 23.I.2008, N.F.O. Mota et al. 1229 (BHCB, INPA, SP); campina no final da estrada Perdida, 23.IX.2011, N.F.O. Mota et al. 2316 (BHCB, INPA, NY, SP); grade do PPBio, 17.X.2011, N.F.O. Mota et al. 2405 (INPA, SP).

\section{Morphological comments}

$X$. cryptantha is distinguished by its oblong to obovoid spikes, with sterile bracts erect and conspicuously longer than the fertile bracts, hiding the main axis of the spike. The laminae are terete to subterete and the sheaths have floccose-ciliate margins. Its trilocular ovary with axial placentation is unique among the species in the area. Xyris oxylepis Idobro \& L.B.Sm., known from savannas of Colombia and Venezuela is remarkably similar to $X$. cryptantha in its often solitary habit, leaf shape, and trilocular ovary. However, $X$. oxylepis differs by its ellipsoid to fusiform spikes, with sterile bracts not hiding the axis of spike.

2.2 Xyris dilatatiscapa Kral \& Jan.-Jac., Novon 8: 399, f. 1. 1998.

Figs. 3b, 4e-i, $7 \mathrm{~g}$

Annual, aquatic, rare terrestrial, clumpforming, rarely solitary. Base of the plant flattened, without mucilage. Leaves $1.2-5 \mathrm{~cm}$ long, distichous, erect to spreading, not twisted; sheaths $1 / 6-2 / 3$ the leaf length, gradually dilating toward the base, papillose, with prominent nerves, reddish to purple, margins scarious, long ciliate, eligulate; lamina $1-4.5 \mathrm{~cm} \times 0.5-0.8 \mathrm{~mm}$, terete in fresh material, canaliculate and involute when dried, densely papillose to undulate-rugose, nerves evident, margins undifferentiated, glabrous, apex obtuse. Spathe longer than the leaves. Peduncle $7.9-16.7 \mathrm{~cm}$ long, $0.1-0.2 \mathrm{~mm}$ wide, filiform, subterete, with its distal $1-3.3 \mathrm{~cm}$ portion abruptly dilated to $0.5 \mathrm{~mm}$ wide, not twisted, glabrous, mostly smooth, transversely rugose-scabridulous or rugulose-papillate in dilated region, ecostate. Spike 4-6-flowered, 4-8 × 2-6 mm, ellipsoid, pale to purple. Sterile bracts 4 , the lower ones ca. $1 / 2$ of the fertile bracts; the uppermost elliptic to oval-lanceolate, not keeled, maculate, margins scarious, entire to slightly lacerate, glabrous, apex obtuse. Fertile bracts $3-4.2 \times 0.1-0.2 \mathrm{~mm}$, elliptic, margins glabrous, scarious, entire to slightly lacerate, pale brown, apex acute; macula along the distal $1 / 2$ of the fertile bract, lanceolate, green, gray or purple. Lateral sepals $2.5-4 \mathrm{~mm}$, elliptic, slightly asymmetric to asymmetric, free, shorter than the bracts, keel glabrous; corolla lobes elliptic; staminodia glabrous, the branches flattened; stamens $1.5 \mathrm{~mm}$ long; anther $1 \mathrm{~mm}$ long, sagittate; style $3.5 \mathrm{~mm}$ long, branches 1.6 mm long; ovary $1.8 \mathrm{~mm}$ long, unilocular, central placentation, with column three-branched distally. Capsule 3-3.5 mm long, globous. Seeds 0.5-0.7 × 0.2-0.3 mm, cylindric-ellipsoid to obovoid, reddish to castaneous, apiculate apex; striae 3-4 per 100 $\mu \mathrm{m}$ of seed width in the midle portion, strong prominent, straight, smooth, with prominent and evenly distributed cross-lines, reticulate.

\section{Morphological comments}

Xyris dilatatiscapa are usually partially submerged plants, occurring in peaty bogs, where they form dense clumps of an unusual bluish to purplish color. The species has some morphological peculiarities, such as a noticeable distal dilation on the peduncle (from which the epithet is derived) and the leaves are cylindrical to canaliculated, and strongly papillose to undulate-rugose. Xyris dilatatiscapa has glabrous staminodia, as does $X$. savanensis, which differs by its flattened leaves and peduncle not distally dilated. Other features that distinguish this species among others in VNP are the central placentation with the column distally threebranched, and seeds with several conspicuously thickened longitudinal and transverse striae, which is unusual amongst Xyris from the VNP.

\section{Distribution and habitat}

Xyris dilatatiscapa was previously known only from the type collection (J. Jansen-Jacobs et al. 2734) collected from a lowlands savanna in Guyana (Kral \& Jansen-Jacobs 1998). It occurs in seasonal lakes in the campinaranas in VNP.

Representative material examined: Grade do PPbio, C.B. Curty et al. 10 (BHCB, INPA, SP); estrada perdida, primeira campina após a guarita, margem esquerda, 12.X.2011, N.F.O. Mota et al. 2344 (BHCB, INPA, NY, SP); grade PPbio, 17.X.2011, P.A. Pereira et al. 112 (INPA, SP).

2.3 Xyris fallax Malme, Bih. Kongl. Svensk. Vetensk.-Akad. Handl. 22, Afd. 3, no. 2: 12, pl. 1, f. 5.1896 .

Figs. 3c, $4 \mathrm{j}-\mathrm{n}, 7 \mathrm{~h}$

Perennial, terrestrial or aquatic, densely clump-forming. Base of the plant not flattened, 

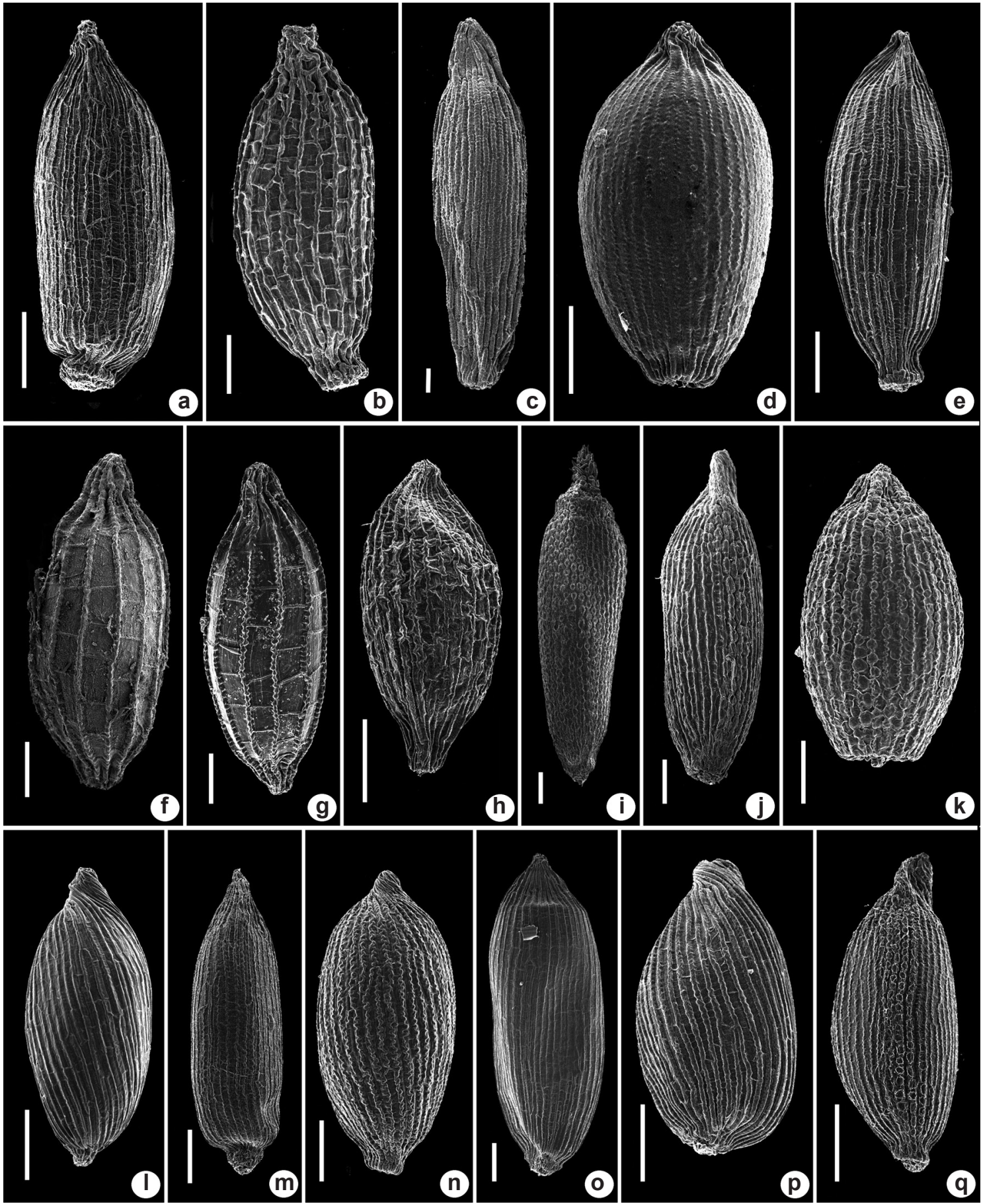

Figure 3 - Scanning electron micrographs of Xyris seeds from Viruá National Park, Brazil. a. X. cryptantha (N.F.O. Mota et al. 2316); b. X. dilatatiscapa (N.F.O. Mota et al. 2344); c. X. fallax (N.F.O. Mota et al. 2305); d. X. guianensis (N.F.O. Mota et al. 2397); e. X. involucrata (N.F.O. Mota et al. 2318); f. X. jupicai (N.F.O. Mota et al. 2311); g. X. macrocephala (N.F.O. Mota et al. 2441); h. X. malmeana (N.F.O. Mota et al. 2310); i. X. mima (N.F.O. Mota et al. 2400); j. X. paraensis (N.F.O. Mota et al. 2308); k. X. savanensis (N.F.O. Mota et al. 2320); 1. X. subglabrata (N.F.O. Mota et al. 2315); m. X. subuniflora (N.F.O. Mota et al. 2399); n. X. surinamensis (N.F.O. Mota et al. 2323); o. X. uleana var. angustifolia (N.F.O. Mota et al. 2327); p. X. uleana var. uleana (N.F.O. Mota et al. 2402); q. Xyris sp.1 (N.F.O. Mota et al. 2324). Scale bars $=100 \mu \mathrm{m}$. 
with mucilage. Leaves 17-65 cm long, spiral, erect to spreading, not twisted; sheaths $1 / 2-1 / 5$ the leaf length, gradually dilating toward the base, smooth, with prominent nerves, pale to reddish, lustrous, margins scarious, ciliate close to the base, ligulate; lamina $12-52 \mathrm{~cm} \times 2.6-5.2 \mathrm{~mm}$, flattened, smooth, nerves slightly evident, margins undifferenciated or slightly incrassate, glabrous, apex incurved-acute, minutely scabrociliate. Spathe shorter than the leaves. Peduncle 52-101.2 cm long, 1.2-2 mm wide, terete, without distal dilatation, twisted, glabrous, smooth, multicostulate, becoming ecostulate toward the apex. Spike 15-26(-35)-flowered, 8-25 × 5-12 mm, globous, subglobous, ovoid, ellipsoid or cylindric, castaneous. Sterile bracts 10-20, the lower ones scale-like, less than $2 \mathrm{~mm}$ long, shorter than the fertile bracts and grading into them; the uppermost oblong to obovate, not keeled, maculate, margins entire to slightly lacerate, glabrous, apex obtuse, round. Fertile bracts 4.2-5.5 $\times 2.2-3.5 \mathrm{~mm}$, broadly oblong to obovate, margins glabrous, entire to slightly lacerate, pale brown, apex obtuse; macula along the distal $1 / 3$ of the fertile bract, elliptic, seldom triagular, greenish, castaneous or gray, with a distinctive midnerve. Lateral sepals $2-5.1 \mathrm{~mm}$, linear-oblanceolate, symmetric to slightly asymmetric, free, shorter than the bracts, keel lacerociliate; corolla lobes obovate; staminodia long-penicillate, branches not flat; stamens $2.5 \mathrm{~mm}$ long; anther $1.5 \mathrm{~mm}$ long, sagittate; style $3.5 \mathrm{~mm}$ long, branches $2 \mathrm{~mm}$ long; ovary $3 \mathrm{~mm}$ long, unilocular, perietal placentation. Capsule 5-5.5 mm long, broadly obovoid. Seeds $1.3-1.5 \times 0.3-0.4 \mathrm{~mm}$, cylindric-fusiform, angulate, reddish to castaneous and translucent, apex acute; striae $2-3$ per $100 \mu \mathrm{m}$ of seed width in the midle portion, strongly prominent, straight, strongly sinuous, cross-lines absent.

\section{Morphological comments}

Xyris fallax is a polymorphic species, with spikes that vary in length and shape. Two morphotypes can be recognized in the study area: one with ellipsoid to cylindrical spikes longer than $2 \mathrm{~cm}$ (e.g., N.F.O. Mota et al. 2341), and the other with ovoid spikes, shorter than $2 \mathrm{~cm}$ (e.g., N.F.O. Mota et al. 2430). The former grows at the margins of perennial lakes, while the latter was observed in sandy, seasonally flooded savannas. $X$. fallax is also characterized by the presence of hyaline mucilage at the base of the leaves, as in $X$. jupicai and X. macrocephala, which also occur in the study area. All three are included in Xyris sect. Xyris, characterized by unilocular ovary with parietal placentation (Seubert 1855). Xyris. fallax is easily distinguished by its multicostulate peduncles and seeds that are longer than $1 \mathrm{~mm}$; angulose; with thickened, sinuous, and strongly prominent longitudinal striae. Peduncles of X. jupicai and $X$. macrocephala have 2- or fewer-costate and seeds shorter than $1 \mathrm{~mm}$, with sparsely and evenly distributed longitudinal and transverse striae.

\section{Distribution and habitat}

Xyris fallax is a pantropical species, known from Africa, Central America and South America. In Brazil, it occurs throughout the North, Midwest, Northeast and Southeast regions (Wanderley et al. 2014). In VNP and surroundings, this species usually grows in areas with human disturbance, such as artificial lakes and roadside vegetation.

Representative material examined: campina, trilha N4 (2500) PPbio, F.A. Carvalho et al. 877 (INPA); estrada Perdida, campina próxima à guarita do parque, 22.IX.2011, N.F.O. Mota et al. 2303 (BHCB, INPA, NY, SP); grade do PPBio, 23.X.2011, N.F.O. Mota et al. 2430 (BHCB, INPA, NY, SP).

2.4 Xyris guianensis Steud., Syn. P1. Glum. 2: 285. 1855.

Figs. 3d, 4o-r, $7 \mathrm{i}$

Type: Guyana: Guiana anglica. 1848, R.H. Schomburghk No. 1058 [K000308885] (Lectotype: K!; Isolectotypes: B!, K[K000308886]!, L) Designated by Kral (as Schomburgk 1038; 1988). Xyris gardneri Malme, Bih. Kongl. Svensk. Vet-Akad. Handl. 26, Afd. 3(19); 8, pl. 1, f. 1. 1901. Type. Brazil: Ceará, 1838, G. Gardner. 1058. (Lectotype: S [S6574!]; Isolectotype, NY!).

Xyris filiscapa Malme, Repert. Spec. Nov. Regni Veg. 3: 112. 1906. Type. Brazil: Amazonas: "In arenosis humidis. Manaos. Amazonas. Brasil." E. H. G. Ule 6172 (Lectotype: S [S6571!]; Isolectotypes: L, NY!, US!).

Xyris connosepala Lanj. \& Lindeman, Bull. Torrey Bot. Club 75: 639. 1948, syn. nov. Type. Suriname: Tafelberg (Table Mountain). Frequent, wet sphagnum-filled cracks in rocks, Savanna No. IV, 16 VIII 1944, B. Maguire et al. 24395 a (Holotype: NY!; Isotype: U).

Annual, terrestrial, rare aquatic, clumpforming, rarely solitary. Base of the plant flattened, without mucilage. Leaves $0.8-7.6 \mathrm{~cm}$ long, distichous, erect, slightly spreading flabellate, often twisted at the apex; sheaths $1 / 3-1 / 5$ the leaf 
length, gradually dilating toward the base, smooth, without prominent nerves, castaneous, margins scarious, glabrous, ligulate; lamina $0.6-5.8 \mathrm{~cm}$ $\times 0.4-1.5 \mathrm{~mm}$, flattened, smooth, nerves slightly evident, margins pale cartilaginous, glabrous, apex incurved acute, slightly cartinlaginous thickened, papillose, with short tricomes. Spathe shorter or equaling the leaves length. Peduncle 1.8-25.5 cm long, $0.1-0.3 \mathrm{~mm}$ wide, filiform, terete, without distal dilatation, not twisted to sligthly twisted, glabrous, smooth, ecostate to 1-costulate. Spike 2-3-flowered, 3-8 $\times 1-4 \mathrm{~mm}$, ellipsoid to obconic, castaneous. Sterile bracts 4 , the lower ones $1 / 2-2 / 3$ of the fertile bracts; the uppermost ovate-triagular, not keeled, maculate, margins undifferenciated, becoming lacerate with age, glabrous, apex acute. Fertile bracts $2-4 \times 0.5-1.5 \mathrm{~mm}$, ovate, margins glabrous, undifferenciated becoming lacerate with age, concolor, apex acute; macula along the distal $1 / 2$ of the fertile bract, oval-lanceolate, green to purple. Lateral sepals $2-3 \mathrm{~mm}$, lanceolate, slightly asymmetric, free to connate on its $1 / 3$ basal portion, exert, keel shortly ciliate; petals connate, corolla lobes broadly obovate; staminodia with sparse penicillate hairs distally, on its typically flattened branches; stamens $1 \mathrm{~mm}$ long; anther $0.7 \mathrm{~mm}$ long, oblong with prominent connective; style $1.5 \mathrm{~mm}$ long, branches $1 \mathrm{~mm}$ long; ovary $1.3 \mathrm{~mm}$ long, unilocular, central placentation. Capsule 2.5-3 $\mathrm{mm}$ long, ellipsoid. Seeds 0.3-0.5 × 0.2-0.3 mm, broadly ellipsoid to obovoid, reddish to castaneous, apiculate apex; striae 5-6 per $100 \mu \mathrm{m}$ of seed width in the midle portion, slightly prominent, straight, sinuous, cross-lines absent.

\section{Morphological comments}

Xyris guianensis is characterized by its narrow, flabellate, and ligulate leaves, with thickened margins, incurved apex, and papillate surface; and ellipsoid to obconic spikes, usually with strongly exserted sepals.

These features are shared with the type material of $X$. connosepala, leading Kral (1988) to treat it as close related to $X$. guianensis, differing by the level of sepals connation and seed shape and ornamentation. According to Kral (1988), while in $X$. guianensis the sepals are free and the seeds are ovoid to ellipsoid, in $X$. connosepala the sepals are fused in the basal $1 / 3$ and the seeds are ellipsoid and strongly striate. However, our analyses revealed that these characters do not support the segregation of both species, because they can vary even within the same individual. Some specimens of $X$. guianensis from VNP (e.g., G.O. Silva et al. 96; N.F.O. Mota et al. 2299, 2313) have lateral sepals free to connate at the base, even in the same spike. Although sepal connation is usually considered taxonomically useful in the genus, being uniform in the majority of species, plasticity is seen in some species, such as in X. uleana, and X. thysanolepis Maguire \& L.B.Sm., in Venezuela (Kral 1988).

The study of seed ornamentation in the type specimen of $X$. connosepala and the material collected at the VNP (Table 1), here treated as $X$. guianensis, did not reveal any significant distinction. All of the seeds examined are about $0.5 \mathrm{~mm}$ long, ellipsoid to ovoid, with longitudinal, slightly thickened, and sinuous striae. Thus, $X$. connosepala is proposed as a new synonym for $X$. guianensis.

\section{Distribution and habitat}

Xyris guianensis is widespread in low to medium elevation savannas in northern Brazil; and southern Colombia, Venezuela, Guyana, and Suriname. In Brazil it occurs in Amazonas, Pará, and Roraima states. The species is commonly found growing in campinaranas of VNP, forming dense clumps, and is often sympatric with $X$. subuniflora and Abolboda killipii.

Representative material examined: estrada Perdida, campina próxima à guarita do parque, 22.IX.2011, N.F.O. Mota et al. 2299 (BHCB, INPA, NY, SP); estrada Perdida, campina próxima à $1^{\text {a }}$. buera da estrada Perdida, 23.IX.2011, N.F.O. Mota et al. 2313 (BHCB, INPA, NY, SP); grade do PPBio, 17.X.2011, N.F.O. Mota et al. 2397 (BHCB, INPA, NY, SP).

2.5 Xyris involucrata Nees in Hooker, J. Bot. 2: 397. 1840. Figs. 3e, 4s-w, 7j

Perennial, terrestrial, solitary to clumpforming. Base of the plant flattened, with mucilage. Leaves 13-28.5 cm long, distichous, spreading flabellate, not twisted; sheaths $1 / 2-3 / 5$ the leaf length, gradually to abruptly dilated at the base, smooth, with prominent nerves, pale to yellowish, castaneous at the very base, margins indiferenciated to slightly scarious, glabrous, eligulate; lamina 8-13 cm $\times 2.6-6.3 \mathrm{~mm}$, flattened, smooth, with two peripherical evident nerves, margins slightly incrassate, densely ciliate, apex obtuse or incurvedobtuse. Spathe equaling the length leaves. Peduncle $38-60 \mathrm{~cm}$ long, $3.2-3.6 \mathrm{~mm}$ wide, ancipital, strongly flattened distally, not twisted to sligthly twisted, densely ciliate, smooth, 1-costate at the 


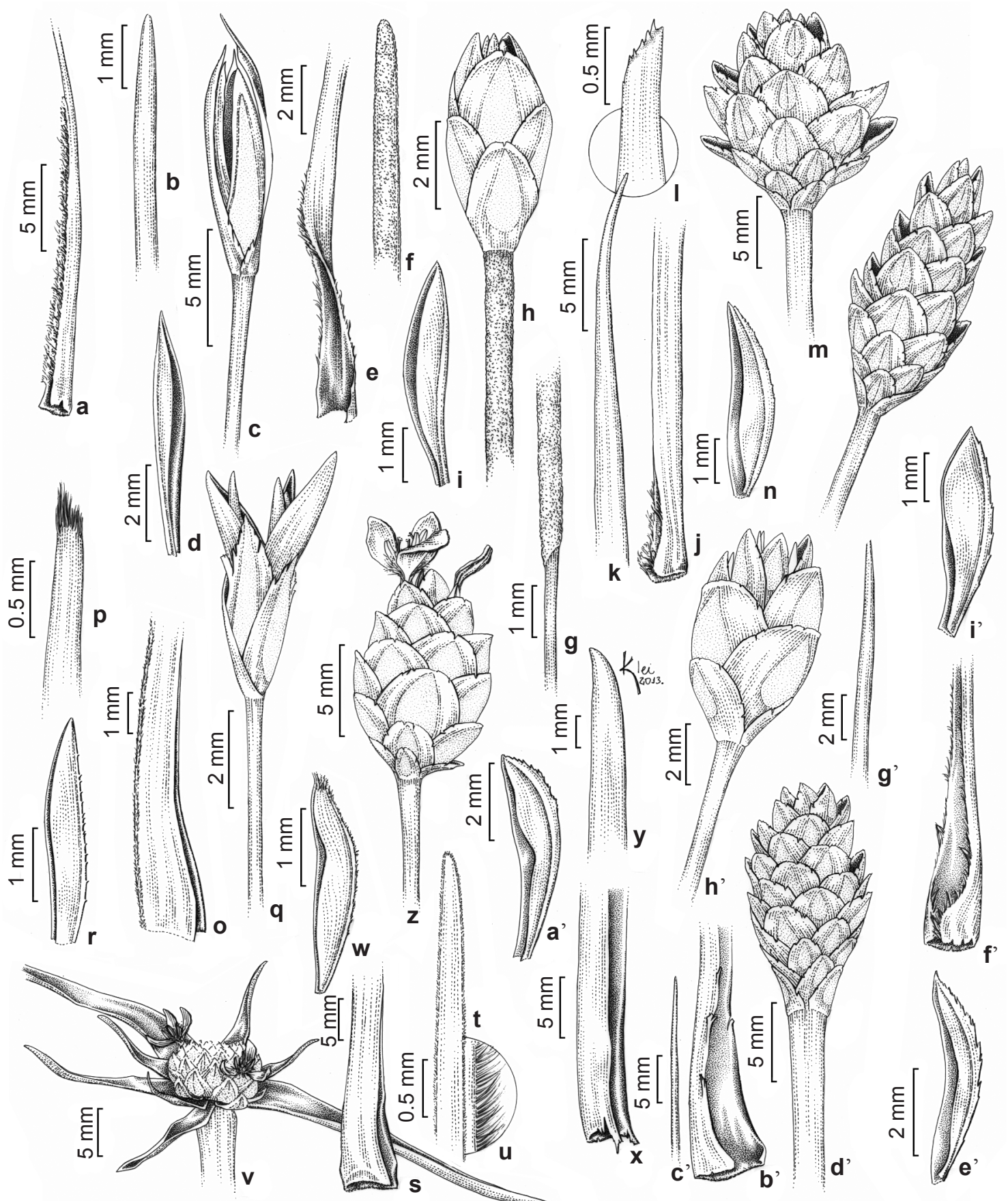

Figure 4 - Species of Xyris from Viruá National Park. a-d. Xyris cryptantha -a. leaf sheath; b. leaf apex; c. spike; d. lateral sepal (N.F.O. Mota et al. 2316). e-i. X. dilatatiscapa - e. leaf sheath; f. leaf apex; g. detail of the dilatated distal peduncle; h. spike; i. lateral sepal (with papillose to undulate-rugose surface) (N.F.O. Mota et al. 2344). j-n. X. fallax-j. leaf sheath; k. leaf apex; 1.leaf apex, minutely scabrociliate at the tip; m. spikes, the upper, morphotype ovoid, shorter than $2 \mathrm{~cm}$ (N.F.O. Mota et al. 2430), the lower, morphotype ellipsoid to cylindrical, longer than $2 \mathrm{~cm}$ (N.F.O. Mota et al. 2341); n. lateral sepal (other details from N.F.O. Mota et al. 2341). o-r.X. guianensis - o. leaf sheath; $p$. leaf apex with short tricomes; q. spike showing the exserted lateral sepals; $r$. lateral sepal (N.F.O. Mota et al. 2397). s-w.X. involucrata -s. leaf sheath; t. leaf apex; u. detail of the densely ciliate leaf margin; v. multiflowered spike with long, patent, sterile bracts; w. lateral sepal (N.F.O. Mota et al. 2318). x-a'.X.jupicai -x. leaf sheath; y. leaf apex; z. spike; a'. lateral sepal (N.F.O. Mota et al. 2311). b'-e'. X. macrocephala -b'. leaf sheath; c'. leaf apex; d'. spike; e'. lateral sepal (N.F.O. Mota et al. 2416). f'-'’. X. malmeana-f'. leaf sheath; g'. leaf apex; h'. spike; i'. lateral sepal (N.F.O. Mota et al. 2310). 
middle portion, two winged. Spike 25-50-flowered, 6-10 × 10-18 mm, hemispherical to subglobous, yellowish to pale. Sterile bracts several, the lower ones distinctly longer than the bracts; the uppermost obtrullate, not keeled, maculate, margins undifferenciated, villosulous-ciliate, apex acute. Fertile bracts $5.1-6.5 \times 3.2-3.6 \mathrm{~mm}$, obtrullate, margins villosulous-ciliate, undifferenciated, reddish, apex acute; macula along the distal $2 / 3$ of the fertile bract, losangular, castaneous to reddish. Lateral sepals $3.5-5 \mathrm{~mm}$, oblong, curved, slightly asymmetric, free, shorter than the bracts, keel ciliolate, trichomes red; corolla lobes elliptic; staminodia long-penicillate, branches not flat; stamens $2 \mathrm{~mm}$ long; anther $1.5 \mathrm{~mm}$ long, oblong; style $5.5 \mathrm{~mm}$ long, branches $2.3 \mathrm{~mm}$ long; ovary 3 $\mathrm{mm}$ long, unilocular, basal placentation. Capsule 3-4 mm long, broadly ellipsoid to obovoid. Seeds $0.5-0.7 \times 0.2-0.3 \mathrm{~mm}$, ellipsoid-cylindric, dark amber, apiculate apex; striae 4-5 per $100 \mu \mathrm{m}$ of seed width in the midle portion, slightly prominent, straight, slightly sinuous, with thin cross-lines, not reticulate.

\section{Morphological comments}

Xyris involucrata is characterized by its multiflowered spikes with several patent sterile bracts that are distinctly longer than the main axis of the spike. Because of these features, it resembles $X$. spruceana Malme, a species widely distributed in the Amazonian savannas, and X. pallidula Kral \& Wand., known only from its type locality, in Amazonas state, Brazil. However, X. spruceana includes plants with inflorescences shorter than $25 \mathrm{~cm}$, contrasting with those of up to $60 \mathrm{~cm}$ of $X$. involucrata. Xyris pallidula, is a similar size to $X$. involucrata, but can be differentiated by its undifferenciated and glabrous leaf margin, while the latter has laminae with margins conspicuously thickened and densely ciliate. Aditionally, $X$. pallidula and $X$. spruceana can be distinguished from $X$. involucrata by fertile bracts with the apex acuminate-subulate (vs. acute in $X$. involucrata). Xyris involucrata and X. macrocephala, are the only species occurring in VNP that present several flowers at anthesis in a single spike simultaneously.

\section{Distribution and habitat}

This species is widespread in low to high elevation savannas and campinaranas in Brazil, Colombia, Venezuela, the Guianas, and Suriname. In Brazil, Xyris involucrata occurs on Serra do
Aracá and Serra da Neblina (both at lowland savannas and the summit of the massif), and in campinaranas associated with the rivers Madeira, Uatumã, and Negro in Amazonas state and in campinaranas along BR-174 highway in Roraima state.

Material examined: Estrada Perdida, campina próxima a buritizal, 24.I.2008, N.F.O. Mota et al. 1226 (BHCB, INPA, SP); estrada Perdida, campina no final da estrada Perdida, 23.IX.2011, N.F.O. Mota et al. 2318 (BHCB, INPA, NY, SP).

Additional specimen: BRAZIL. Roraima: Município Caracaraí, BR174, km 350, North of Rio Brancinho, 18.XI.1977, W.C. Steward 75 (INPA).

2.6 Xyris jupicai Rich., Actes Soc. Hist. Nat. Paris 1: 106.1792.

Figs. 3f, 4x-a', 7k

Annual, terrestrial or aquatic, solitary to clump-forming. Base of the plant flattened, with mucilage. Leaves $13-55.5 \mathrm{~cm}$ long, distichous to spiral, erect to spreading flabellate, not twisted; sheaths $1 / 2-3 / 5$ the leaf length, gradually dilating toward the base, smooth, with prominent nerves, pale to yellowish, margins scarious, glabrous, ligulate; lamina 7-22.5 $\mathrm{cm} \times 1.4-9 \mathrm{~mm}$, flattened, smooth, nerves slightly evident, margins slightly incrassate, glabrous, apex obtuse to incurved-acute. Spathe shorter than the leaves. Peduncle 22.3-94.5 $\mathrm{cm}$ long, $1.2-1.4 \mathrm{~mm}$ wide, proximally terete, becoming flattened toward the apex, not twisted to sligthly twisted, papillose-tuberculate at the edges, striate, 1-or 2-costate. Spike 18-40-flowered, 7.4$27.4 \times 4.8-8.4 \mathrm{~mm}$, ovoid, obovoid to ellipsoid, green to castaneous. Sterile bracts 10-12, the lower ones scale-like, shorter than the fertile bracts and grading into them; the uppermost oblong to round, not keeled, maculate, margins undifferenciated, glabrous, apex obtuse, round. Fertile bracts 5.5-7.1 $\times$ 4-6.2 mm, broadly obovate, margins glabrous, undifferenciated, concolor, apex obtuse to round; macula along the distal $1 / 3$ of the fertile bract, ovate to triangular, green to gray. Lateral sepals 4.2-6 $\mathrm{mm}$, linear, oblong-curved or obovate-curved, symmetric to slightly asymmetric, free, shorter than the bracts, keel lacerate from middle to the apex; corolla lobes broadly obovate; staminodia long-penicillate, branches not flat; stamens 2 $\mathrm{mm}$ long; anther $1.2 \mathrm{~mm}$ long, oblong; style 4.8 $\mathrm{mm}$ long, branches $1.5 \mathrm{~mm}$ long; ovary $3 \mathrm{~mm}$ long, unilocular, parietal placentation. Capsule 5-6 mm long, obovoid. Seeds $0.5-0.8 \times 0.2-0.3$ $\mathrm{mm}$, ellipsoid, pale, apex apiculate, dark; striae 2 per $100 \mu \mathrm{m}$ of seed width in the midle portion, 
strong prominent, straight, slightly sinuous, with prominent and evenly distributed cross-lines, reticulate.

\section{Morphological comments}

Xyris jupicai is widely distributed with a noticeable morphological plasticity. It is similar to $X$. macrocephala, with which it forms a complex of difficult to delimit entities. In VNP individuals of intermediate morphology were not observed, here the species were easily distinguished. Plants of $X$. jupicai are annual, smaller than $1 \mathrm{~m}$, while those of $X$. macrocephala are robust, always taller than one meter. The pedunle of $X$. jupicai is 1- or 2-costate, terete, and flattened toward the apex, whilst $X$. macrocephala has a subterete to trichetous, ecostate to 2-costate peduncle. Seed morphology is also useful for distinguishing these species: $X$. macrocephala seeds have cross-lines less thickened than the longitudinal striae; in $X$. jupicai, the cross-lines and longitudinal striae are equally thickened.

\section{Distribution and habitat}

This species is widespread occurring from North America to South America (Argentina), at low elevations. In Brazil it is known from all states. Xyris jupicai and X. macrocephala occur in disturbed environments, growing in the study area in humid areas, close to roads and other anthropic areas.

Representative material examined: Grade do PPBio, 23.X.2011, N.F.O. Mota et al. 2429 (INPA, NY, SP); estrada Perdida, campina próxima à $1^{\mathrm{a}}$. buera da estrada Perdida, 23.IX.2011, N.F.O. Mota et al. 2311 (BHCB, INPA, NY, SP); grade PPBio, 11.X.2011, C.T. Pedrollo et al. 125 (BHCB, INPA, SP).

2.7. Xyris macrocephala Vahl., Enum. Pl. 2: 204. 1805. Figs. 3g, 4b'-e', 71

Perennial, terrestrial or aquatic, solitary to clump-forming. Base flattened, robust, with mucilage. Leaves 38-64 cm long, distichous to spiral, erect or spreading flabellate, not twisted; sheaths more than $1 / 2$ of the leaf length, gradually to abruptly dilating toward the base, smooth, with sligthly prominent nerves, castaneous, red to purple at the base, margins scarious to entire, glabrous, eligulate; lamina $36-40 \mathrm{~cm} \times 4.2-8.6$ $\mathrm{mm}$, flattened, smooth, striate, nerves not evident, margins slightly incrassate, glabrous, apex incurved-acute to straight-acute. Spathe shorter than the leaves. Peduncle 113-122 cm long, 3-4 $\mathrm{mm}$ wide, subterete to trichetous, without distal dilatation, not twisted, glabrous, smooth to striate, ecostate to 2-costate. Spike 25-35-flowered, $20.8-30.5 \times 12-15.4 \mathrm{~mm}$, ovoid to cylindric, green to dark brown. Sterile bracts $16-22$, the lower ones bracts much smaller than the fertile bracts and grading into them; the uppermost obovate to ovate or suborbicular, not keeled, maculate, margins undifferenciated, glabrous, apex obtuse, round. Fertile bracts $3.5-5.7 \times 3.5-5.5 \mathrm{~mm}$, obovate to ovate or suborbicular, margins glabrous, undifferenciated, concolor, apex obtuse to round; macula along the distal $1 / 3$ of the fertile bract, ovate to round, green to gray. Lateral sepals 4-7 $\mathrm{mm}$, linear to oblong-curved, slightly asymmetric, free, shorter than the bracts, keel lacerate or lacerofimbriate; corolla lobes obovate; staminodia long-penicillate, branches not flat; stamens 2.2 $\mathrm{mm}$ long; anther $1.5 \mathrm{~mm}$ long, sagittate; style 8.5 $\mathrm{mm}$ long, branches $3 \mathrm{~mm}$ long; ovary $3.5 \mathrm{~mm}$ long, unilocular, parietal placentation. Capsule 5-7 mm long, obovoid. Seeds $0.6-0.7 \times 0.2-0.3$ $\mathrm{mm}$, ellipsoid, pale, apiculate apex; striae 1-2 per $100 \mu \mathrm{m}$ of seed width in the midle portion, strong prominent, straight, moniliform, with thin and evenly distributed cross-lines, reticulate.

\section{Morphological comments}

Plants of Xyris macrocephala are robust, more than $1 \mathrm{~m}$ tall, with hyaline mucilage on the plant base. The spikes are multiflowered (more than 25 flowers). For observations about its affinities, see comments under $X$. fallax and $X$. jupicai.

\section{Distribution and habitat}

Xyris macrocephala is widespread in South America, occurring at low to medium elevation. In Brazil, it is reported from all states. In VNP the species is locally rare, and was observed in one a disturbed, flooded campinarana.

Material examined: margem esquerda, próximo à ponte do Rio Barauana, 19.X.2011, N.F.O. Mota et al. 2416 (BHCB, INPA, NY, SP)

Additional specimen: BRAZIL. Roraima: Boa Vista, BR-174 Boa Vista-Caracaraí, savanas adajcentes à estrada, 22.IX.2011, N.F.O. Mota and P.L. Viana 2298 (BHCB, INPA).

2.8. Xyris malmeana L.B.Sm., Bol. Inspetoria Fed. Obras Contra Secas 10: 126. 1939.

Figs. 3h, 4f'-i', $7 \mathrm{~m}$

Perennial, terrestrial, solitary, rarely clumpforming. Base of the plant sub-bulbous, without mucilage. Leaves 5.5-28.2 cm long, distichous, 
erect, twisted or not; sheaths 1/3-2/5 the leaf length, abruptly dilated at the base, smooth, with prominent nerves, pale to reddish, lustrous, castaneous at very base, margins scarious, long ciliate, eligulate; lamina $3.3-20 \mathrm{~cm} \times 0.8-2 \mathrm{~mm}$, flattened, finely rugose, nerves slightly evident, margins slightly incrassate, glabrous, apex acute, acuminate to subulate. Spathe shorter than the leaves. Peduncle $22-51.2 \mathrm{~cm}$ long, $0.7-0.8 \mathrm{~mm}$ wide, terete to subterete, filiform, without distal dilatation, twisted, glabrous, smooth to finely rugose, 3 or 4-costate. Spike 8-12-flowered, 5.3-7.5 $\times 2-6.1 \mathrm{~mm}$, broadly ellipsoid or ovoid, reddish to castaneous. Sterile bracts 4 , the lower ones ca. 1/2-1/3 of the fertile bracts; the uppermost elliptic to obovate, not keeled, maculate, margins undifferenciated, glabrous, apex obtuse, round. Fertile bracts 3-6.2 $\times 2.2-3.1 \mathrm{~mm}$, broadly elliptic to obovate, margins glabrous, undifferenciated, concolor, apex obtuse to round; macula along the distal $1 / 3$ to $2 / 3$ of the fertile bract, oval-lanceolate, green to gray. Lateral sepals 4-5.5 mm, obovate, incurved, oblong-curved to elliptic-curved, asymmetric, free, shorter than the bracts, keel entire to lacero-ciliolate; corolla lobes obovate; staminodia long-penicillate, branches not flat; stamens $2 \mathrm{~mm}$ long; anther $1.2 \mathrm{~mm}$ long, oblong; style $4 \mathrm{~mm}$ long, branches $1.5 \mathrm{~mm}$ long; ovary $3.2 \mathrm{~mm}$ long, unilocular, basal placentation. Capsule 4.5-5 $\mathrm{mm}$ long, broadly ellipsoid. Seeds $0.4 \times 0.1-0.2 \mathrm{~mm}$, ellipsoid, castaneous, apiculate apex; striae 5-7 per $100 \mu \mathrm{m}$ of seed width in the midle portion, prominent, straight, smooth, with thin cross-lines, not reticulate.

\section{Morphological comments}

Xyris malmeana is characterized by solitary individuals, which were erect, with a bulbous base, and the peduncle clearly 3- or 4-costate. The spikes are small (never longer that $8 \mathrm{~mm}$ ), with fertile bracts with a narrow macula, and margins entire to slightly lacerate when senescent. Xyris malmeana resembles $X$. lacerata Pohl ex Seub., a widely distributed species in South America, in the shape of spikes (ellipsoid to ovoid), the peduncle at least 3-costate, and the solitary and erect habit. Xyris lacerata differs with a more robust and strongly bulbous base, and fertile bracts with a broad macula and lacerate margins. The lateral sepals of $X$. lacerata are lacerate-ciliate, whereas in $X$. malmeana, they are ciliolate.

\section{Distribution and habitat}

A Neotropical species, known from sandy savannas in low to medium elevations of Brazil,
Venezuela, Trinidad, and in the Guianas. In Brazil, it occurs in the states of Amapá, Amazonas, Goiás, Maranhão, Mato Grosso, Pará and Roraima.

Representative material examined: Estrada Perdida, campina próxima à guarita do parque, 22.IX.2011, N.F.O. Mota et al. 2310 (BHCB, INPA, NY, SP); grade do PPBio, 13.IX.2010, S.M. Costa et al. 725 (INPA, UEC); rio Anauá, 24.III.2011, S.M. Costa et al. 997 (INPA).

2.9 Xyris mima L.B.Sm. \& Downs, Proc. Biol. Soc. Wash. 73: 250, f. 4. $1960 . \quad$ Figs. 3i, 5a-f, 7n Annual, terrestrial, rare aquatic, solitary to clump-forming. Base of the plant flattened, without mucilage. Leaves 3-24 cm long, distichous, erect or spreading flabellate, twisted or not; sheaths less than $1 / 2$ the leaf length, gradually dilating toward the base, papillate to densely rugose, with strongly prominet nerves, castaneous to reddish, margins scarious, glabrous, ligulate; lamina $2-18 \mathrm{~cm} \times$ 2-5 mm, flattened, densely transversely rugose, nerves evident, margins turbeculate-scabrid, glabrous, apex incurved-acute. Spathe shorter than the leaves. Peduncle 8-52 cm long, 2-4 mm wide, subterete, without distal dilatation, often becoming flattened toward the apex, not twisted to sligthly twisted, strong tuberculate-scabrid, rugose, 2-costate. Spike 15-35-flowered, 4-25 $\times 2-5 \mathrm{~mm}$, ovoid to cylindric, castaneous. Sterile bracts 4 , the lower ones $1 / 2$ of the fertile bracts; the uppermost obovate, not keeled, maculate, margins undifferenciated, glabrous, apex obtuse, round. Fertile bracts $3-5 \times 3-5 \mathrm{~mm}$, obovate to round, margins glabrous, undifferenciated, concolor, apex broadly round; macula along the distal $1 / 3$ of the fertile bract, not reaching the margin, broadly ovate, green to gray. Lateral sepals 3-3.5 $\mathrm{mm}$, oblong-curved to elliptic-curved, strongly asymmetric, free, shorter than the bracts, keel ciliate; corolla lobes broadly obovate; staminodia long-penicillate, branches not flat; stamens $1 \mathrm{~mm}$ long; anther $0.5 \mathrm{~mm}$ long, sagittate; style $3.5 \mathrm{~mm}$ long, branches $1.3 \mathrm{~mm}$ long; ovary $1.8 \mathrm{~mm}$ long, unilocular, basal placentation. Capsule $2.5-3 \mathrm{~mm}$ long, obovoid. Seeds $1-1.1 \times 0.3 \mathrm{~mm}$, ellipsoid to obovoid, castaneous, apex acute with a coma of bristles; striae 4-5 per $100 \mu \mathrm{m}$ of seed width in the midle portion, prominent, straight, moniliform, cross-lines absent.

\section{Morphological comments}

Xyris mima is recognizable by the densely rugose leaf and peduncle surface, presence of a ligule, scarious leaf sheaths, and usually cylindrical 


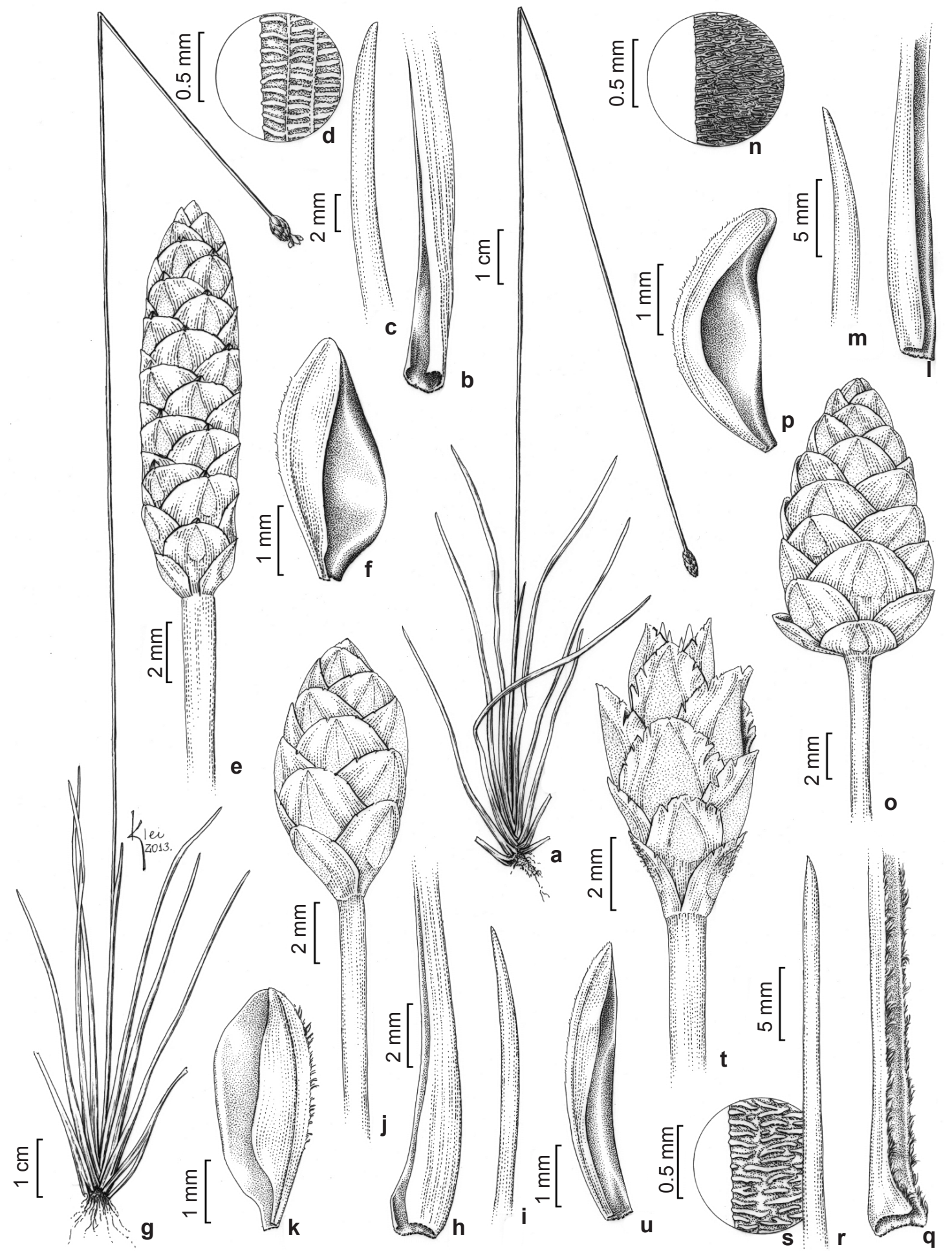

Figure 5 - Species of Xyris from Viruá National Park. a-f. Xyris mima - a. habit; b. leaf sheath; c. leaf apex; d. detail of the undulate-rugose leaf surface; e. spike; f. lateral sepal (N.F.O. Mota et al. 2312). g-k. X. paraensis - g. habit; h. leaf sheath; i. leaf apex; j. spike; k. lateral sepal (N.F.O. Mota et al. 2422). 1-p. X. savanensis - 1. leaf sheath; m. leaf apex; n. detail of rugose leaf surface; o. spike; p. lateral sepal (N.F.O. Mota et al. 2302). q-u. X. subglabrata - q. leaf sheath; r. leaf apex; s. detail of the rugose leaf surface; t. spike; u. lateral sepal (G.O. Silva et al. 97). 
spikes. These characters suggest a superficial affinity with $X$. savanensis. However, $X$. mima has a 2-costate peduncle, pilose staminodia, and ellipsoid to obovoid seeds about $1 \mathrm{~mm}$ long, with monilliform striae and an apical coma of bristles, while $X$. savanensis has an ecostate peduncle, glabrous staminodia, and smaller $(\sim 0.5 \mathrm{~mm})$, narrowly ellipsoid seeds, with alternate groups of monilliform and sinuous striae, and typically a truncate base and acute and glabrous apex. Both species become reddish ferruginous (the whole plant) when senescent, composing beautifully colored fields in VNP.

\section{Distribution and habitat}

Xyris mima is known from Brazil and Venezuela. In Brazil, it occurs in the states of Amazonas, Pará and Roraima, this being the first record in the latter state. In VNP $X$. mima is commonly found growing in wet, sometimes flooded, sandy campinaranas.

Representative material examined: Estrada Perdida, campina próxima à $1^{\mathrm{a}}$. bueira, 23.IX.2011, N.F.O. Mota et al. 2312 (BHCB, INPA, NY, SP); estrada Perdida, campina cerca de $1 \mathrm{~km}$ depois da segunda bueira, 23.IX.2011, N.F.O. Mota et al. 2320 (BHCB, INPA, NY, SP); grade do PPBio, 17.X.2011, N.F.O. Mota et al. 2400 (BHCB, INPA, NY, SP).

2.10 Xyris paraensis Poepp. ex Kunth, Enum. P1.4: 9. 1843. Figs. 3j, $5 \mathrm{~g}-\mathrm{k}$

Annual, terrestrial, solitary to clump-forming. Base of the plant flattened, without mucilage. Leaves 2-13 cm long, distichous, erect or spreading flabellate, usually not twisted; sheaths $1 / 3-1 / 2$ the leaf length, gradually dilating toward the base, smooth, with sligthly prominent nerves, castaneous to reddish, margins scarious, glabrous, eligulate; lamina $1.5-8 \mathrm{~cm} \times 1-3 \mathrm{~mm}$, flattened, smooth, nerves evident, margins undifferentiated, glabrous, apex acute. Spathe shorter or equaling the leaves length. Peduncle $8-31 \mathrm{~cm}$ long, $0.3-0.7 \mathrm{~mm}$ wide, terete, without distal dilatation, not twisted to sligthly twisted, glabrous, smooth, ecostate. Spike 10-15-flowered, 3.2-7.4 × 2-4.5 mm, ovoid, castaneous. Sterile bracts 4 , the lower ones $1 / 2$ of the fertile bracts; the uppermost obovate, not keeled, maculate, margins undifferenciated, glabrous, apex obtuse. Fertile bracts $2-4 \times 1.5-3.5$ $\mathrm{mm}$, obovate, margins glabrous, undifferenciated, concolor, apex obtuse; macula along the distal 1/3 of the fertile bract, broadly ovate, green to gray.
Lateral sepals $0.8-3.5 \mathrm{~mm}$, elliptic to obovatecurved, strongly asymmetric, free, shorter than the bracts, keel glabrous, ciliate to slightly lacerate; corolla lobes broadly obovate; staminodia longpenicillate, branches not flat; stamens $1.4 \mathrm{~mm}$ long; anther $1.1 \mathrm{~mm}$ long, oblong; style $3.5 \mathrm{~mm}$ long, branches $1.3 \mathrm{~mm}$ long; ovary $2.7 \mathrm{~mm}$ long, unilocular, basal placentation. Capsule 1-2.2 mm long, ellipsoid. Seeds $0.7-0.8 \times 0.2-0.3 \mathrm{~mm}$, ellipsoid, castaneous, apex strongly apiculate; striae 4-5 per $100 \mu \mathrm{m}$ of seed width in the midle portion, prominent, straight, forming groups of moniliform and smooth striae, cross-lines absent.

\section{Morphological comments}

Xyris paraensis can be distinguished from other congeners in the study area by the following set of characteristics: lamina surface smooth with prominent nerves, sheaths with margins scarious and glabrous, absence of a ligule, and peduncle smooth and ecostate. Seeds of Xyris paraensis are about $0.8 \mathrm{~mm}$ long, with a strongly apiculate apex, and alternate groups of moniliform and smooth striae. Several specimens previously identified as $X$. paraensis in the herbaria studied were erroneously identified as X. mima or X. savanensis. The latter two species closely resemble $X$. paraensis in their usually caespitose habit, with distichous, erect to spreading flabellate leaves, and scarious and glabous sheaths. The spikes of all three species are usually ovoid with bracts with a narrow ovate to triangular macula. Both X. mima and X. savanensis differ from $X$. paraensis by their strongly rugose laminae and peduncle and seed shape. In X. mima, the seeds are longer than $1 \mathrm{~mm}$, with an apical coma of bristles, and the striae are all moliniform. Seeds of $X$. savanensis are smaller (less than $0.5 \mathrm{~mm}$ long), with a truncate base, acute apex, and sinuous and moniliform striae. These species comprise a nomenclatural and morphological complex that deserves further detailed investigation.

\section{Distribution and habitat}

Xyris paraensis is known from Brazil, Venezuela, the Guianas in South American and Belize, in Central American. In Brazil it occurs in the states of Amapá, Amazonas, Ceará, Maranhão, Mato Grosso, Pará, Pernambuco Piauí and Roraima. Few populations with scattered individuals were found in the study area.

Representative material examined: Grade do PPBio, 17.X.2011, C.B. Curty et al. 8 (INPA), 15.I.2006, F.R.C. 
Costa et al. 1530 (INPA); estrada perdida, campina na margem esquerda próximo à $1^{\mathrm{a}}$. bueira, 21.X.2011, N.F.O. Mota et al. 2422 (BHCB, INPA, NY, SP).

2.11 Xyris savanensis Miq., Linnaea 18: 605. 1844.

Figs. 3k, 5l-p, $7 \mathrm{o}$

Annual, terrestrial or aquatic, solitary to clump-forming. Base of the plant flattened, soft, without mucilage. Leaves $3.2-23.8 \mathrm{~cm}$ long, distichous, erect to spreading flabellate, not twisted; sheaths less than $1 / 2$ the leaf length, gradually dilating toward the base, papillose, papillate to densely rugose, castaneous to reddish, margins scarious, glabrous, ligulate; lamina $2-19 \mathrm{~cm} \times$ $1.2-2.6 \mathrm{~mm}$, flattened, papillose to densely rugose, nerves evident, margins incrassate, glabrous to papillose, apex acute to incurved-acute. Spathe shorter than the leaves. Peduncle $12-54.5 \mathrm{~cm}$ long, $0.6-1.3 \mathrm{~mm}$ wide, terete to subterete, without distal dilatation, not twisted to sligthly twisted, glabrous, smooth, papillose to densely rugose, ecostate. Spike 10-35-flowered, 3.7-21.2 × 2.4-8.5 mm, ovoid to cylindric, ellipsoid or subglobous, reddish to castaneous. Sterile bracts 4 , the lower ones $1 / 2$ of the fertile bracts; the uppermost orbicular, not keeled, maculate, margins undifferenciated, glabrous, apex round. Fertile bracts 3-5.2 × 2.9-5 $\mathrm{mm}$, obovate, suborbicular to orbicular, margins glabrous, undifferenciated, concolor, apex round; macula along the distal $1 / 2$ of the fertile bract, triangular, green to gray. Lateral sepals $3-4 \mathrm{~mm}$, elliptic-curved, strongly asymmetric, free, shorter than the bracts, keel ciliate to ciliolate; corolla lobes obovate; staminodia glabrous, branches not flat; stamens $1.2 \mathrm{~mm}$ long; anther $0.6 \mathrm{~mm}$ long, oblong; style $3.3 \mathrm{~mm}$ long, branches $1 \mathrm{~mm}$ long; ovary 1 $\mathrm{mm}$ long, unilocular, basal placentation. Capsule 2-2.5 mm long, broadly obovoid. Seeds $0.4-0.5$ $\times 0.3 \mathrm{~mm}$, broadly ellipsoid to ovoid, reddish to castaneous, apex acute; striae 5-6 per $100 \mu \mathrm{m}$ of seed width in the midle portion, prominent, straight, mixing moniliforms and sinuous striae, cross-lines absent.

\section{Morphological comments}

Xyris savanensis is highly plastic morphologically and has a broad geographic distribution. It is distinguished by its glabrous staminodia, seeds smaller than $0.5 \mathrm{~mm}$ long with monilliform longitudinal striae, and leaves and peduncle strongly rugose (except for $X$. savanensis var. glabrata Seub., which does not occur in the study area, and has a smooth leaf and peduncle surface). See comments under X. mima.

\section{Distribution and habitat}

Xyris savanensis is widely distributed throughout tropical South America. In Brazil, it is known to occur in all states. In VNP $X$. savanensis is found on sandy campinaranas sympatric with $X$. mima, and is often being confused with it.

Representative material examined: Estrada para Serra do Preto, 23.I.2008, N.F.O. Mota et al. 1228 (BHCB, INPA, NY, SP); estrada perdida, primeira campina após a guarita, margem esquerda, 10.X.2011, N.F.O. Mota et al. 2340 (INPA); estrada Perdida, após a $3^{\text {a }}$ bueira próximo ao $2^{\circ}$. igarapé, 20.IX.2010, S.M. Costa et al. 784 (INPA, NY, UEC).

2.12 Xyris subglabrata Malme, Bull. Torrey Bot. Club 58: 322. $1931 . \quad$ Figs. 31, 5q-u, 7p

Perennial, terrestrial, clump-forming. Base of the plant sub-bulbous, without mucilage. Leaves 5-23.4 cm long, spiral, erect, not twisted; sheaths $1 / 3-1 / 10$ the leaf length, abruptly dilated at the base, rugose, rarely smooth, with strongly prominet nerves, reddish to brown, margins indiferenciated to slightly scarious, densely long ciliate, eligulate; lamina 3-17 cm $\times 0.4-1.2 \mathrm{~mm}$, terete, subterete, often sulcate, papillose to smooth, nerves slightly evident, margins undifferentiated, glabrous, apex conic, some times pilose-tufted. Spathe shorter than the leaves. Peduncle 10-34.5 cm long, 0.7-1 mm wide, terete, becoming subterete toward the apex, slightly twisted, glabrous, smooth to papillose, ecostate. Spike 10-15-flowered, 5-8 × 3-7 mm, ovoid, ellipsoid, subglobous, globous to obovoid, dark brown. Sterile bracts $6-8$, the lower ones $1 / 2$ of the fertile bracts; the uppermost obovate to orbicular, not keeled, maculate, margins lacerate, glabrous, apex obtuse. Fertile bracts 5-7 $\times 2-2.5 \mathrm{~mm}$, obovate to oblong, margins glabrous, lacerate, concolor, apex obtuse; macula along the distal $1 / 3$ to $1 / 2$ of the fertile bract, triangular, green to gray, becoming dark with age. Lateral sepals 5-6 mm, linear to lanceolate, curved, asymmetric, free, shorter than the bracts, keel ciliolate above de middle; corolla lobes broadly obovate; staminodia long-penicillate, branches not flat; stamens $3 \mathrm{~mm}$ long; anther $1.5 \mathrm{~mm}$ long, sagittate; style $6.5 \mathrm{~mm}$ long, branches $3 \mathrm{~mm}$ long; ovary $3 \mathrm{~mm}$ long, unilocular, central placentation. Capsule 2.8-4 mm long, obovoid to cilindric. Seeds $0.6-0.7 \times 0.2-0.3 \mathrm{~mm}$, cylindric-fusiform, reddish to castaneous, apiculate apex; striae $6-8$ per 100 
$\mu \mathrm{m}$ of seed width in the midle portion, prominent, straight, smooth to slightly sinuous, with thin crosslines, not reticulate.

\section{Morphological comments}

Plants of Xyris subglabrata are small, rarely taller than $15 \mathrm{~cm}$. The leaves and peduncle are terete to subterete, the spikes are blackish and small (about $8 \mathrm{~mm}$ long), 10-15-flowered. Because of the nigrescence of its bracts, the macula, although present, is hardly visible, especially in dried specimens. In the study area X. subglabrata and $X$. surinamensis are often sympatric that can be misidentified if not carefully examined. Xyris surinamensis can be distinguished from $X$. subglabrata by its clearly flattened leaves and peduncle, brownish spikes to $23 \mathrm{~mm}$ long, 12-20-flowered, and the clearly visible macula.

\section{Distribution and habitat}

Common in lowland sandy savannas and campinaranas in northern Brazil (Amazonas and Roraima), Colombia and Venezuela. In the study area, it occurs in campinaranas.

Representative material examined: campina no final da estrada Perdida, 23.IX.2011, N.F.O. Mota et al. 2315 (BHCB, INPA, NY, SP); estrada perdida, $1^{\text {a }}$. campina após a guarita, margem esquerda, 10.X.2011, N.F.O. Mota et al. 2339 (INPA); grade do PPBio, 17.X.2011, N.F.O. Mota et al. 2398 (BHCB, INPA, NY, SP).

2.13 Xyris subuniflora Malme, Recueil Trav. Bot. Néerl. 9: 129. 1912. Figs. 3m, 6a-d, 7r

Annual, terrestrial or aquatic, clump-forming. Base of the plant flattened, soft, without mucilage. Leaves 1-5.5 cm long, distichous, erect to spreading flabellate, not twisted; sheaths $1 / 2$ or less than the leaf length, gradually dilating toward the base, smooth, without prominet nerves, pale, reddish to pink, margins scarious, glabrous, ligulate; lamina $0.5-3.8 \mathrm{~cm} \times 0.2-0.5 \mathrm{~mm}$, flattened, filiform, smooth, nerves not evident, margins undifferentiated, glabrous, apex incurved-acute. Spathe equaling the length leaves. Peduncle $1-12 \mathrm{~cm}$ long, $0.1-0.3 \mathrm{~mm}$ wide, terete, filiform, without distal dilatation, not twisted, glabrous, smooth to papillose, ecostate. Spike 1-2-flowered, 3-4 × 1-2 mm, narrowly ellipsoid, castaneous to dark brown. Sterile bracts 4, the lower ones smaller than the bracts; the uppermost lanceolate, slightly keeled, maculate, margins undifferenciated, glabrous, apex acute. Fertile bracts $3-4 \times 0.6-0.8$ $\mathrm{mm}$, lanceolate, naviculate, margins glabrous, undifferenciated, concolor, apex acute; macula along the distal $1 / 2$ of the fertile bract, lanceolate, green, castaneous, becoming reddiish wih age. Lateral sepals 2.5-3 mm, narrowly triangular, connate on more than its half portion, lobes asymmetric, incluse, not keeled; corolla lobes broadly obovate; staminodia long-penicillate, branches not flat; stamens $1.5 \mathrm{~mm}$ long; anther $1 \mathrm{~mm}$ long, oblong; style $2.8 \mathrm{~mm}$ long, branches $0.7 \mathrm{~mm}$ long; ovary $2 \mathrm{~mm}$ long, unilocular, basal placentation. Capsule 1.8-2 mm long, broadly ellipsoid. Seeds $0.4-0.5 \times 0.1-0.2 \mathrm{~mm}$, broadly ellipsoid, castaneous, apiculate apex; striae 5-7 per $100 \mu \mathrm{m}$ of seed width in the midle portion, prominent, twisted toward the apex, sinuous, cross-lines absent.

\section{Morphological comments}

Xyris subuniflora includes some of the smallest plants known in the genus so far $(1-12 \mathrm{~cm}$ tall). It can be distinguished by its filiform leaves and peduncles, 1- or 2-flowered spikes and connate sepals. The tiny size and morphological peculiarities cited above make it easily distinguished from the other species in the study area.

\section{Distribution and habitat}

The species is common in lowland compinaranas in northern Brazil, Colombia and Suriname. In Brazil, it occurs in the states of Amazonas, Pará and Roraima. Plants form dense clumps and are commonly sympatric with $A$. killipii and $X$. guianensis, and are frequently mixed with the latter in herbarium specimens.

Representative material examined: Rio Anauá, 31.VII.2011, C.E. Zartman 8522 (INPA); estrada para Serra do Preto, 23.I.2008, N.F.O. Mota et al. 1230 (BHCB, INPA, NY, SP); estrada Perdida, campina no final da estrada, 23.IX.2011, N.F.O. Mota et al. 2317 (BHCB, INPA, NY, SP); grade PPBio, 17.X.2011, N.F.O. Mota et al. 2399 (BHCB, INPA, NY, SP).

2.14 Xyris surinamensis Spreng., Tent. Suppl.: 2. 1828. Figs. 3n, 6e-i, 7s

Perennial, terrestrial, clump-forming. Base of the plant bulbous, hard-fibrous, without mucilage. Leaves $9.5-38 \mathrm{~cm}$ long, spiral, erect to spreading, often twisted; sheaths $1 / 3-1 / 2$ the leaf length, abruptly dilated at the base, verrucous to rugose, rare smooth, with sligthly prominet nerves, castaneous to reddish, margins reddish, densely rugose, long ciliate, eligulate; lamina $6-25.5 \mathrm{~cm}$ $\times 1-3.5 \mathrm{~mm}$, flattened, smooth to rugose, palepuncticulate, nerves strongly evident, margins incrassate, glabrous, apex incurved-acute to 


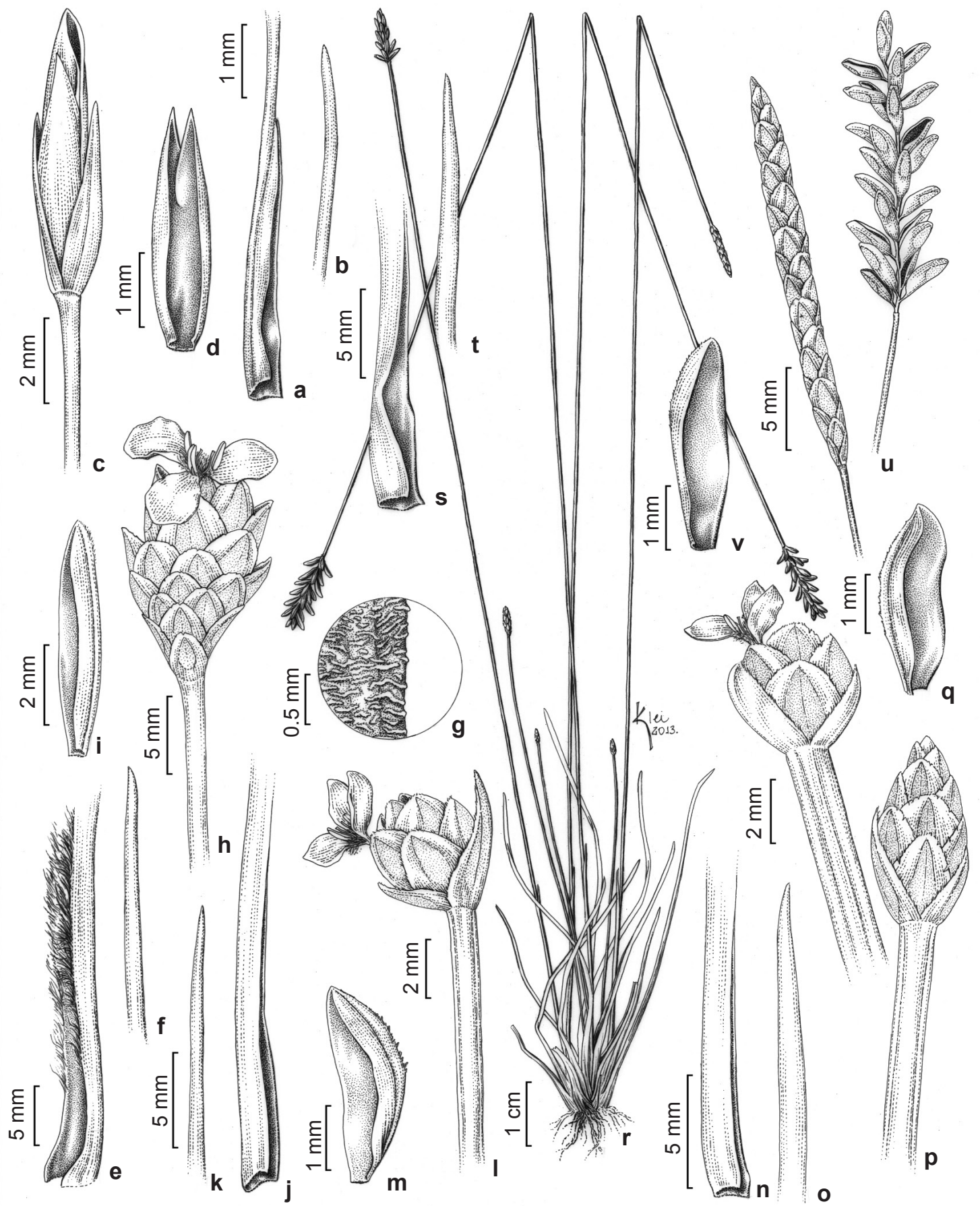

Figure 6 - Species of Xyris from Viruá National Park. a-d. Xyris subuniflora - a. leaf sheath; b. leaf apex; c. spike; d. lateral sepals, connate at the base (N.F.O. Mota et al. 2399). e-i. X. surinamensis - e. leaf sheath; f. leaf apex; g. detail of the rugose leaf surface; h. spike; i. lateral sepal (N.F.O. Mota et al. 2300). j-m. X. uleana var. angustifolia - j. leaf sheat; k. leaf apex; 1. spike; m. lateral sepal (N.F.O. Mota et al. 2327). n-q. X. uleana var. uleana - n. leaf; sheath; o. leaf apex (N.F.O. Mota et al. 2440); p. spike shapes, the upper globous (N.F.O. Mota et al. 2306), the lowest ovoid (N.F.O. Mota et al. 2440); q. lateral sepal (N.F.O. Mota et al. 2306). r-v. Xyris sp.1 - r. habit; s. leaf sheath; t. leaf apex; u. spikes, the upper a senescent spike with persistent bracts, the lower a flowering spike; $v$. lateral sepal (N.F.O. Mota et al. 2324). 

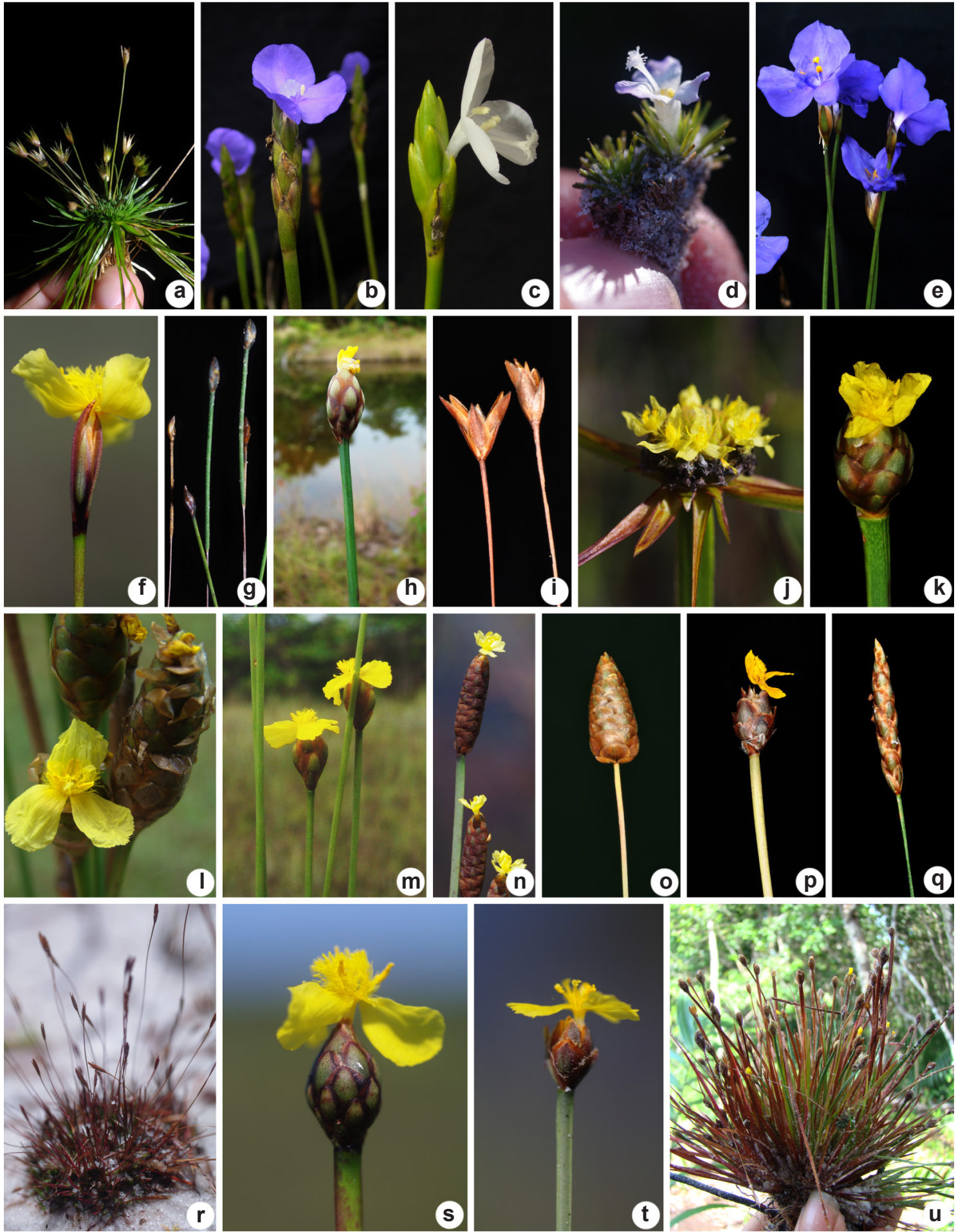

Figure 7 - Xyridaceae in Viruá National Park, Brazil - a. Abolboda americana; b-c. A. macrostachya; d. A. killipii; e. A. pulchella; f. Xyris cryptantha; g. X. dilatatiscapa; h. X. fallax; i. X. guianensis; j. X. involucrata; k. X. jupicai; 1. X. macrocephala; m. X. malmeana; n. X. mima; o. X. savanensis; p. X. subglabrata; q. Xyris sp. $1 ;$ r. X. subuniflora; s. X. surinamensis; t. X. uleana var. angustifolia; u. X. uleana var. uleana. Photographs by P.L.Viana (a, d, f, g, j, n, r, t), N.F.O. Mota (b, c, h, i, k-m, o-q, s, u) S.M. Costa \& T.D.M. Barbosa (e). 
incurved-round. Spathe shorter or longer than the leaves length. Peduncle $15-42.5 \mathrm{~cm}$ long, 2-5 mm wide, flattened, without distal dilatation, twisted or not, glabrous, smooth to strongly rugose, 2-costate. Spike 12-20-flowered, 5-23 × 5-15 mm, ellipsoid, subglobous to broadly turbinate when dried, ovoid in fresh material, golden castaneous. Sterile bracts 18-22, the lower ones $1 / 3$ of the fertile bracts; the uppermost obovate to oblong, not keeled, maculate, margins undifferenciated, glabrous, apex obtuse. Fertile bracts $9-10 \times 4-5 \mathrm{~mm}$, oblong to obovate, margins glabrous, undifferenciated, concolor, apex obtuse; macula along the distal $1 / 3$ to $1 / 2$ of the fertile bract, triangular, green to gray. Lateral sepals 5-7 $\mathrm{mm}$, linear to linear-oblanceolate, asymmetric, free, shorter than the bracts, keel glabrous to villosulous; corolla lobes broadly obovate; staminodia longpenicillate, branches not flat; stamens $5 \mathrm{~mm}$ long; anther $2.5 \mathrm{~mm}$ long, oblong; style $12 \mathrm{~mm}$ long, branches $5 \mathrm{~mm}$ long; ovary $3.5 \mathrm{~mm}$ long, unilocar, with strong vestigial septa, central placentation. Capsule 0.4-0.6 mm long, obovoid. Seeds 0.8-1 $\times$ 0.3-0.4 mm, cylindric-fusiform, pale to castaneous, apex acute to apiculate; striae 6-7 per $100 \mu \mathrm{m}$ of seed width in the midle portion, prominent, straight, smooth, with thin cross-lines, not reticulate.

\section{Morphological comments}

Xyris surinamensis is easily recognized by distinctly flattened, strongly rugose leaves and peduncles, and long-ciliate leaf sheath margins. For further notes about morphological affinities, see comments under $X$. subglabrata.

\section{Distribution and habitat}

Xyris surinamensis is probably one of the most widespread species in northern South American, occurring in Brazil, Colombia, Venezuela, and the Guianas. In Brazil, it occurs in the states of Amazonas, Pará and Roraima. In VNP it is widespread in campinaranas.

Representative material examined: Grade PPBio, 15.I.2006, F.R.C. Costa et al.1677 (INPA); estrada Perdida, campina próxima à guarita do parque, 22.IX.2011, N.F.O. Mota et al. 2300 (BHCB, INPA, NY); campina no final da estrada Perdida, 23.IX.2011, N.F.O. Mota et al. 2314 (BHCB, INPA, NY).

2.15 Xyris uleana Malme var. angustifolia Lanj., Bull. Misc. Inform. Kew 1939(10): 562. 1940.

Figs. 3o, 6j-m, $7 \mathrm{t}$

Annual, terrestrial, solitary, rarely clumpforming. Base of the plant flattened, thin, without mucilage. Leaves 2.7-5.2 cm long, distichous, erect, not twisted; sheaths less than 1/2 the leaf length, gradually dilating toward the base, sparsely papillose to smooth, with strongly prominet nerves, pale to gold, margins scarious, glabrous, ligulate; lamina $1.3-5.5 \mathrm{~cm} \times 0.3-0.5 \mathrm{~mm}$, flattened, smooth, nerves evident, margins thin, glabrous, apex acute to incurved-acute. Spathe shorter than the leaves. Peduncle 3-13 cm long, 0.3-0.8 mm wide, terete, without distal dilatation, not twisted, glabrous, smooth, 2-costate. Spike 6-8-flowered, 3-5 × 1.8-4 $\mathrm{mm}$, ovoid to subglobous, castaneous. Sterile bracts 4 , the lower ones equal or longer than the fertile bracts, with excurrent apex; the uppermost ovate to elliptic, keeled, maculate, margins scarious, ciliate, apex obtuse. Fertile bracts 2.5-3 × 1.5-1.8 mm, oblong to obovate, margins ciliate, scarious, reddish, apex obtuse; macula along the distal 1/3 of the fertile bract, ovate to triangular, green to gray. Lateral sepals 2.2-3 mm, elliptic, strongly asymmetric, free to connate close to the base, shorter than the bracts, keel sparsely ciliate; corolla lobes broadly obovate; staminodia long-penicillate, branches not flat; stamens $0.8 \mathrm{~mm}$ long; anther $0.5 \mathrm{~mm}$ long, oblong; style $3.7 \mathrm{~mm}$ long, branches $1 \mathrm{~mm}$ long; ovary $1.2 \mathrm{~mm}$ long, unilocular, basal placentation. Capsule 1-1.5 mm long, obovoid. Seeds 0.3-0.4 × $0.2 \mathrm{~mm}$, broadly ellipsoid, reddish to castaneous, apiculate apex; striae 6-7 per $100 \mu \mathrm{m}$ of seed width in the midle portion, prominent, twisted, smooth to slightly sinuous, with thin cross-lines, not reticulate.

\section{Morphological comments}

Xyris uleana var. angustifolia are small plants, never more than $13 \mathrm{~cm}$ long. If differs from $X$. uleana var. uleana by its narrower, almost filiform leaves, (<0.5 mm vs. 0.6-2.5 mm wide), and terete peduncle (vs. anciptal). These features approach $X$. uleana var. angustifolia and $X$. calderonii Kral, L.B.Sm. \& Wand., known only from its type locality in Amazonas state, Brazil. Xyris calderonii, however, has shorter sepals $(2-2.5 \mathrm{~cm}$ vs. $2.5-3 \mathrm{~cm})$ and reticulate seeds (vs. not reticulate).

\section{Distribution and habitat}

Xyris uleana var. angustifolia is known from northern Brazil, Venezuela, and the Guianas. In Brazil, it occurs in the states of Amazonas, Pará and Roraima, occurring in dense, graminoid savannas. It the VNP, can be found in sympatry with $X$. uleana var. uleana. Representative material examined: Estrada Perdida, lago na margem, após $2^{\mathrm{a}}$. bueira, 17.I.2011, M.C.E. Amaral et al. 39 (INPA); campina próxima à $1^{\text {a }}$. bueira 
Table 1 - Comparative seed characters of Xyris species occurring in Viruá National Park, Roraima state, Brazil. Acronyms: F - with thin cross-lines, not reticulate; PR - with prominent and evenly distributed cross-lines, reticulate; FR - with thin and evenly distributed cross-lines, reticulate; A - cross-lines absent.

\begin{tabular}{|c|c|c|c|c|c|}
\hline Species & Length (mm) & Shape & Apex & Type of striae & Cross-line \\
\hline Xyris cryptantha & $0.4-0.5$ & ovoid to ellipsoid & apiculate & sinuous & $\mathrm{F}$ \\
\hline$X$. dilatatiscapa & $0.5-0.7$ & $\begin{array}{c}\text { cylindric-ellipsoid to } \\
\text { obovoid }\end{array}$ & apiculate & smooth & PR \\
\hline X. fallax & $1.3-1.5$ & $\begin{array}{c}\text { cylindric-fusiform, } \\
\text { angulate }\end{array}$ & acute & sinuous & A \\
\hline$X$. guianensis & $0.3-0.5$ & $\begin{array}{c}\text { broadly ellipsoid to } \\
\text { obovoid }\end{array}$ & apiculate & sinuous & A \\
\hline$X$. involucrata & $0.5-0.7$ & ellipsoid-cylindric & apiculate & sinuous & $\mathrm{F}$ \\
\hline X. jupicai & $0.5-0.8$ & ellipsoid & apiculate & sinuous & PR \\
\hline X. macrocephala & $0.6-0.7$ & ellipsoid & apiculate & moniliform & FR \\
\hline X. malmeana & 0.4 & ellipsoid & apiculate & smooth & $\mathrm{F}$ \\
\hline X. mima & $1.0-1.1$ & ellipsoid to obovoid & $\begin{array}{c}\text { acute with coma } \\
\text { of bristles }\end{array}$ & moniliform & A \\
\hline X.paraensis & $0.7-0.8$ & ellipsoid & strongly apiculate & $\begin{array}{l}\text { moniliform and } \\
\text { smooth }\end{array}$ & A \\
\hline X. savanensis & $0.4-0.5$ & $\begin{array}{c}\text { broadly ellipsoid to } \\
\text { ovoid }\end{array}$ & acute & $\begin{array}{l}\text { moniliform and } \\
\text { sinuous }\end{array}$ & A \\
\hline X. subglabrata & $0.6-0.7$ & cylindric-fusiform & apiculate & $\begin{array}{l}\text { s mooth to } \\
\text { sinuous }\end{array}$ & $\mathrm{F}$ \\
\hline X. subuniflora & $0.4-0.5$ & broadly ellipsoid & apiculate & sinuous & A \\
\hline X. surinamensis & $0.8-1.0$ & cylindric-fusiform & acute to apiculate & smooth & $\mathrm{F}$ \\
\hline$X$. uleana var. angustifolia & $0.3-0.4$ & broadly ellipsoid & apiculate & $\begin{array}{c}\mathrm{smooth} \text { to } \\
\text { sinous }\end{array}$ & $\mathrm{F}$ \\
\hline X. uleana var. uleana & $0.5-0.7$ & broadly ellipsoid & apiculate & $\begin{array}{l}\text { moniliform and } \\
\text { smooth }\end{array}$ & $\mathrm{F}$ \\
\hline Xyris sp.1 & $0.4-0.6$ & ellipsoid & apiculate & smooth & $\mathrm{F}$ \\
\hline
\end{tabular}

Table 2 - Comparative characters of the seeds of Xyris connosepala Lanj. \& Lindeman and Xyris guianensis Steud.

\begin{tabular}{lcccccc}
\hline Species & Length & Shape & Apex & Type of striae & Cross-lines & Color \\
\hline Xyris connosepala & $\leq 0.5$ & ellipsoid & apiculate & sinuous & absent & castaneous \\
X. guianensis & $\leq 0.5$ & broadly ellipsoid to obovoid & apiculate & sinuous & absent & castaneous \\
\hline
\end{tabular}

na estrada Perdida, 23.IX.2011, N.F.O. Mota et al. 2327 (BHCB, INPA, NY); estrada Perdida, próximo a $2^{\text {a }}$ bueira, 16.IX.2010, S.M. Costa et al. 753 (INPA, UEC).

2.16 Xyris uleana var. uleana Malme, Repert. Spec. Nov. Regni Veg. 3: 113. 1906.

Figs. $3 p, 6 n-q, 7 u$

Annual, terrestrial or aquatic, clump-forming, rarely solitary. Base of the plant flattened, soft, without mucilage. Leaves $2-11.4 \mathrm{~cm}$ long, distichous, erect or spreading flabellate, not twisted; sheaths $1 / 2$ or a little bit more the leaf length, gradually dilating toward the base, sparsely papillose to smooth, with strongly prominet nerves, reddish to brown, margins scarious, glabrous, eligulate; lamina $1-4.2 \mathrm{~cm} \times 0.6-2.5 \mathrm{~mm}$, strongly flattened, smooth, nerves evident, margins thin, glabrous, apex acute to incurved-acute. Spathe mostly shorter than the leaves. Peduncle (1.2-)3.5$26.2 \mathrm{~cm}$ long, 1-2 $\mathrm{mm}$ wide, ancipital, becoming flattened towars the apex, not twisted to sligthly twisted, glabrous to scaberolous-ciliate, smooth, ecostate or with two lateral costae in each wing. Spike (5-)10-25-flowered, 2.6-10 × 1.1-3.6 mm, 
broadly to narrowly ovoid, castaneous. Sterile bracts 4 , the lower ones distinctly longer than the fertile bracts, with excurrent apex; the uppermost ovate to elliptic, keeled, maculate, margins scarious, ciliate, apex obtuse. Fertile bracts $1.5-3.5 \times 0.7-3 \mathrm{~mm}$, broadly obovate to suborbicular, margins ciliate, scarious, reddish, apex obtuse; macula along the distal $1 / 3$ of the fertile bract, ovate to triangular, green to gray. Lateral sepals $1.4-3 \mathrm{~mm}$, ellipticcurved to obovate-curved, strongly asymmetric, free to connate close to the base, shorter than the bracts, keel ciliate to ciliolate; corolla lobes broadly obovate; staminodia long-penicillate, branches not flat; stamens $0.8 \mathrm{~mm}$ long; anther $0.5 \mathrm{~mm}$ long, oblong; style $3 \mathrm{~mm}$ long, branches $0.6 \mathrm{~mm}$ long; ovary $1.5 \mathrm{~mm}$ long, unilocular, basal placentation. Capsule $1.5-3 \mathrm{~mm}$ long, broadly obovoid. Seeds $0.5-0.7 \times 0.3 \mathrm{~mm}$, broadly ellipsoid, reddish to castaneous, apiculate apex; striae $4-5$ per $100 \mu \mathrm{m}$ of seed width in the midle portion, prominent, twisted at the apex, forming groups of moniliform and smooth striae, with few thin cross-lines, not reticulate.

\section{Morphological comments}

Xyris uleana var. uleana are delicate plants that are rarely taller than $15 \mathrm{~cm}$. The species has sterile bracts longer than the main axis of the spike, as in $X$. cryptantha and $X$. involucrata, that also occur in the study area. However, it differs from $X$. cryptantha by its anciptal peduncle (terete in $X$. cryptantha). Xyris involucrata, also with anciptal peduncles, is easily differentiated from X. uleana var. uleana by its larger size (38-60 cm long vs. up to $15 \mathrm{~cm}$ in X. uleana var. uleana) and patent sterile bracts (erect in X. uleana var. uleana).

\section{Distribution and habitat}

This variety occurs in open formations at low to high elevations in Brazil, Colombia, Venezuela, and Guyana. In Brazil, is found in the states of Amazonas, Goiás, Mato Grosso, Pará, Rondônia and Roraima. It is widespread in the VNP campinaranas.

Representative material examined: Estrada para Serra do Preto, 23.I.2008, N.F.O. Mota et al. 1231 (BHCB, INPA, SP); estrada Perdida, campina próxima à guarita do parque, 22.IX.2011, N.F.O. Mota et al. 2306 (BHCB, INPA, NY, SP); grade do PPBio, 17.X.2011, N.F.O. Mota et al. 2402 (BHCB, INPA, NY, SP).

\subsection{Xyris sp.1}

Figs. 3q, 6r-v, 7q

Annual, terrestrial or aquatic, solitary, rarely clump-forming. Base of the plant flattened, without mucilage. Leaves $1.5-7 \mathrm{~cm}$ long, distichous, erect to spreading, usually not twisted; sheaths $1 / 3-1 / 2$ the leaf length, gradually dilating toward the base, smooth, with prominent nerves, gold, pale to reddish, margins scarious, glabrous, eligulate; lamina $0.8-4.2 \mathrm{~cm} \times 0.2-1 \mathrm{~mm}$, flattened, smooth, nerves evident, margins slightly incrassate, glabrous, apex acute. Spathe shorter or equaling the leaves length. Peduncle 7.5-32 cm long, $0.1-0.7 \mathrm{~mm}$ wide, terete to filiform, without distal dilatation, not twisted, glabrous, smooth, ecostate to 1-costulate. Spike 4-20-flowered, 3-30 × 1-4 $\mathrm{mm}$, cylindric, golden castaneous. Sterile bracts 4, the lower ones smaller to equal than the bracts; the uppermost oblong to obovate, slightly keeled, maculate, margins undifferenciated, glabrous, apex obtuse. Fertile bracts $2.5-4 \times 1.5-2 \mathrm{~mm}$, obovate, margins glabrous, undifferenciated, concolor, apex obtuse to round; macula along the distal $1 / 2$ to $2 / 3$ of the fertile bract, ovate, green to gray. Lateral sepals 2-3 mm, elliptic-curved, asymmetric, free, shorter than the bracts, keel evenly ciliate; corolla lobes obovate; staminodia long-penicillate, branches not flat; stamens $1.2 \mathrm{~mm}$ long; anther 0.5 $\mathrm{mm}$ long, oblong; style $3.5 \mathrm{~mm}$ long, branches $1.3 \mathrm{~mm}$ long; ovary $1.2 \mathrm{~mm}$ long, unilocular, basal placentation. Capsule $2-3 \mathrm{~mm}$ long, broadly obovoid. Seeds $0.4-0.6 \times 0.2 \mathrm{~mm}$, ellipsoid, reddish to castaneous, apiculate apex; striae 6-7 per 100 $\mu \mathrm{m}$ of seed width in the midle portion, slightly prominent, twisted at the apex, smooth, with thin cross-lines, not reticulate.

\section{Morphological comments}

Plants of this species are usually solitary, seldom clump-forming, and are characterized by their golden hue, filiform peduncles, cylindrical spikes 3-7 times longer than wide, free lateral sepals with the keel regularly ciliolate. It is probably a new taxon belonging to the Xyris paraensis complex, but further studies and a detailed inspection of the types of all varieties of this complex are necessary to confirm this hypothesis.

\section{Distribution and habitat}

This morphotype apparently occurs in the states of Amazonas, Pará, and Roraima in Brazil, and Amazonas state in Venezuela. It is widespread in the campinaranas usually growing with $A$. killipii, X. subuniflora and X. mima.

Representative material examined: Estrada Perdida, campina aberta denominada localmente por "Duninhas", 
1.XII.2006, F.A. Carvalho et al. 2 (INPA); estrada Perdida, campina próxima à guarita do parque, 22.IX.2011, N.F.O. Mota et al. 2308 (BHCB, INPA, NY, $\mathrm{SP})$; estrada Perdida, campina ca. $1 \mathrm{~km}$ após $2^{\mathrm{a}}$. bueira na estrada Perdida, 23.IX.2011, N.F.O. Mota et al. 2324 (BHCB, INPA, NY, SP).

\section{Acknowledgements}

The first author gratefully acknowledges funding from CAPES and CNPq for Ph.D. scholarships and PNADB (Programa Nacional de Apoio e Desenvolvimento da Botânica) for grant support. The authors thank ICMBio for providing collection permits and field support, especially Antônio Lisboa and Beatriz Ribeiro Lisboa, as well as all of the staff of Viruá National Park. The aerial photographs are reproduced courtesy of Bruno Mendonça, Antonio Iaccovazo, and Rogério Gribel. We thank Mike Hopkins for help with the fieldwork and specimens, and the curators and staff of the herbaria cited for access to their collections, Klei Sousa for the beautifully rendered illustrations, and Andres Botero for SEM assistance in the Plant Research Laboratory at The New York Botanical Garden. The authors thank Marccus Alves and two anonymous reviewers and for improvements to the manuscript.

\section{References}

Alvares, C.A.; Stape, J.L.; Sentelhas, P.C.; Gonçalves, J.L.M. \& Sparovek G. 2013. Köppen's climate classification map for Brazil. Meteorologische Zeitschrift 22: 711-728.

APG III (Angiosperm Phylogeny Group). 2009. An update of the Angiosperm Phylogeny Group classification for the orders and families of flowering plants: APG III. Botanical Journal of the Linnean Society 161: 122-127.

Barreto, L.C.; Echternacht, L. \& Garcia, Q.S. 2013. Seed coat sculpture in Comanthera (Eriocaulaceae) and its implications on taxonomy and phylogenetics. Plant Systematics and Evolution 299: 1461-1469.

Blomquist, H.L. 1955. The genus Xyris L. in North Carolina. Journal of the Elisha Mitchell Scientific Society 71: 35-46.

Bouchenak-Khelladi, Y.; Muasya, A.M. \& Linder, H.P. 2014. A revised evolutionary history of Poales: origins and diversification. Botanical Journal of the Linnean Society 175: 4-16.

Campbell, L.M. 2004a. Xyridaceae. In: Smith, N.; Mori S. A.; Henderson A.; Stevenson, D.W. \& Heald, S.V. (eds). Flowering plants of the Neotropics. Princeton University Press, Princeton. Pp.492-493.

Campbell, L.M. 2004b. Anatomy and systematics of Xyridaceae, with special reference to Aratitiyopea
Steyerm. \& P.E. Berry. Dissertation. City University of New York, New York. 182 Pp.

Campbell, L.M. 2005. Contributions toward a monograph of Xyridaceae: A revised nomenclature of Abolboda. Harvard Papers in Botany 10: 137-145.

Campbell, L.M. 2008 - onward. The Xyridaceae pages - an electronic monograph. Available at $<\mathrm{http}: / /$ sweetgum.nybg.org/xyridaceae/>. Access on 22 October 2014. The New York Botanical Garden, New York.

Cárdenas-López, D. 2007. Flora del Escudo Guayanés en Inírida (Guainía, Colombia). Instituto Amazónico de Investigaciones Cientícas - Sinchi, Bogotá. 188p.

Chase, M.W.; Soltis, D.E.; Soltis, P.S.; Rudall, P.J.; Fay, M.F.; Hahn, W.H.; Sullivan, S.; Joseph, J.; Molvray, M.; Kores, P.J.; Givnish, T.J.; Sytsma, K.J. \& Pires, J.C. 2000. Higher-level systematics of the monocotyledons: an assessment of current knowledge and a new classification. In: Wilson, K.L. \& Morrison, D.A. (eds.). Monocots: Systematics and Evolution. CSIRO Publishing, Collingwood. Pp. 3-16.

Damasco, G.; Vicentini, A.; Castilho, C.V.; Pimentel, T.P. \& Nascimento, H.E.M. 2013. Disentangling the role of edaphic variability, flooding regime and topography of Amazonian white-sand vegetation. Journal of Vegetation Science 24: 384-394.

Davis, J.I.; Stevenson, D.W.; Petersen, G.; Seberg, O.; Campbell, L.M.; Freudenstein, J.V.; Goldman, D.H.; Hardy, C.R.; Michelangeli, F.A.; Simmons, M.P.; Specht, C.D.; Vergara-Silva, F. \& Gandolfo, M.A. 2004. A phylogeny of the monocots, as inferred from $r b c L$ and atpA sequence variation, and a comparison of methods for calculating jackknife and bootstrap values. Systematic Botany 29: 467-510.

Doust, A.N.L. \& Conn, B.J. 1994. Xyris L. Section Xyris (Xyridaceae) in Australia. Australian Systematic Botany 7: 455-484.

ICMBio (Instituto Chico Mendes de Conservação da Biodiversidade). 2014. Plano de Manejo do Parque Nacional do Viruá. ICMBio, Boa Vista. 626p.

IUCN. 2012. The IUCN Red List of Threatened Species. Version 2012.2. Available at $<$ http://www. iucnredlist.org > . Access on 20 October 2014.

Köppen, W. 1948. Climatologia com um estúdio de los climas de la tierra. Fondo de Cultura e Economica, Buenos Aires. Pp. 1-466.

Kral, R. 1966. Xyris (Xyridaceae) of the continental United States and Canada. Sida 2: 177-260.

Kral, R. 1988. The genus Xyris (Xyridaceae) in Venezuela and contiguous northern South America. Annals of the Missouri Botanical Garden 75: 522-722.

Kral, R. 1992. A treatment of American Xyridaceae exclusive of Xyris. Annals of the Missouri Botanical Garden 79: 819-885. 
Kral, R. 2005. Xyridaceae. In: Berry, P.E.; Yatskievych, K. \& Holst, B.K. (eds.). Flora of the Venezuelan Guayana. Vol. 9. Missouri Botanical Garden Press, St. Louis. Pp. 526-574.

Kral, R. \& Jansen-Jacobs, M. 1998. A new Nematopoid species of Xyris (Xyridaceae) from Guyana. Novon 8: 399-401.

Kral, R. \& Smith, L.B. 1980. Xyridaceae Brasiliae I. Bradea 3: 57-64.

Kral, R. \& Smith, L.B. 1982a. Xyridaceae Brasiliae II. Bradea 3: 273-298.

Kral, R. \& Smith, L.B. 1982b. Xyris apureana Kral \& Smith, a new species of Xyris (sect. Nematopus) from Venezuela. Annals of the Missouri Botanical Garden 69: 412-414.

Kral, R. \& Wanderley, M.G.L. 1988a. Ten novelties in Xyris (Xyridaceae) from the Planalto of Brazil. Annals of the Missouri Botanical Garden 75: 352372.

Kral, R. \& Wanderley, M.G.L. 1988b. Two new Xyris (Xyridaceae) from the Amazon Basin of Brazil. Annals of the Missouri Botanical Garden 74: 912916.

Kral, R. \& Wanderley, M.G.L. 1992. Five new taxa of Xyris L. (Xyridaceae) from Brazil. Kew Bulletin 48: 577-588.

Kral, R. \& Wanderley, M.G.L. 1995. Xyridaceae. In: Stannard, B.L. (ed.). Flora of Pico das Almas, Chapada da Diamantina, Bahia, Brazil. Royal Botanic Gardens, Kew. Pp. 781-802.

Lisboa, P.L. 1975. Estudo sobre a vegetação das campinas Amazônicas: II. Acta Amazônica 5: 211-223.

Lock, J.M. 1998. Notes on the genus Xyris (Xyridaceae) in East Africa. Kew Bulletin 53: 883-895.

Maguire, B. 1958. Xyridaceae. In: Maguire, B.; Wurdack, J.J. \& Collaborators. The botany of the Guayana Highland-Part III. Memoirs of the New York Botanical Garden 10: 1-156.

Maguire, B. \& Smith, L.B. 1964. Xyridaceae. In: Maguire, B.; Wurdack, J.J. \& Collaborators. The botany of the Guayana Highland - Part V. Memoirs of the New York Botanical Garden 10: 1-278.

Maguire, B. \& Wurdack, J.J. 1960. Xyridaceae. In: Maguire; B. Wurdack, J.J. \& Collaborators. The botany of the Guayana Highland - Part IV. Memoirs of the New York Botanical Garden 10: 1-37.

Malmanche, L.-A. 1919. Contribution à l'étude anatomique des Eriocaulonacées et des families voisines: Restiacées, Centrolepidacées, Xyridacées, Philydracées, Mayacacées. Dissertation, Série A, No. 814, Saint Cloud, Imprimeerie Girault. Pp. $1-165$.

Malme, G.O.A. 1896. Die Xyridaceen. der Ernten Regnell'schen expedition. Bihang till Kongliga Svenska Vetenskaps-Akademiens Handlingar 22, III(2): 1-27.
Malme, G.O.A. 1898. Xyridaceae Brasiliensis, praecipue Goyazenis a Glaziou Lectae. Bihang till Kongliga Svenska Vetenskaps-Akademiens Handlingar 24, III(3): 1-20.

Malme, G.O.A. 1901. Beiträge zur XyridaceenFlora Sudamerikas. Bihang till Kongliga Svenska Vetenskaps-Akademiens Handlingar 26, III(19): 1-18.

Malme, G.O.A. 1912. Xyridaceae. Recueil des Travaux Botaniques Néerlandais 9: 129-135.

Malme, G.O.A. 1913a. Xyris L., Untergattung Nematopus (Seubert). Entwurf einer Gliederung. Arkiv för Botanik 13: 1-103.

Malme, G.O.A. 1913b. Die amerikanischen species der gattung Xyris L., untergattung Euxyris (Endlicher). Arkiv för Botanik 13: 1-32.

Malme, G.O.A. 1929. Xyridaceae brasiliensis Hilarianae. Arkiv för Botanik 22A: 1-9.

McNeill, J.; Barrie, F.R.; Buck, W.R.; Demoulin, V.; Greuter, W.; Hawksworth, D.L.; Herendeen, P.S.; Knapp, S.; Marhold, K.; Prado, J.; Pru'Home van Reine, W.F.; Smith, G.F. \& Wiersema, J.H. 2012. International Code of Nomenclature for algae, fungi, and plants (Melbourne Code), Adopted by the Eighteenth International Botanical Congress Melbourne, Australia. Available at $<\mathrm{http}$ ://www.iapttaxon.org/nomen/main.php?page $=$ art11 $>$. Access on 5 February 2013.

Mendonça, B.A.F. 2011. Campinaranas amazônicas. Pedogênese e relações solo-vegetação. Master Dissertation. Universidade Federal de Viçosa, Viçosa, $110 \mathrm{Pp}$.

Mendonça, B.A.F.; Filho, E.I.F.; Schaefer, C.E.G.R.; Carvalho, A.F.; Vale, J.F. \& Corrêa, G.R. 2014. Use of geophysical methods for the study of sandy soils under Campinarana at the National Park of Viruá, Roraima state, Brazilian Amazonia. Journal of Soils and Sediments 14: 525-537.

MMA. 2014. Portaria n 443, de 17 de dezembro de 2014. Brasília, Brazil. Available at $<\mathrm{http}$ ://sintse.tse.jus.br/ documentos/2014/Dez/18/portaria-no-443-de-17-dedezembro-de-2014>. Access on 5 January 2015.

Mota, N.F.O. 2009. A família Xyridaceae no Parque Estadual do Rio Preto, Minas Gerais, Brasil. Master's thesis. Universidade Federal de Minas Gerais, Belo Horizonte. 148p.

Mota, N.F.O. \& Wanderley, M.G.L. 2014. Three new species of Xyris (Xyridaceae) from Diamantina Plateau in Brazil, Minas Gerais. Brittonia 66: 42-50.

Mota, N.F.O. \& Wanderley, M.G.L. 2013. Xyris riopretensis (Xyridaceae): a new species from Minas Gerais, Brazil. Rodriguésia 64: 555-560.

Nilsson, A.L. 1892. Studien über die Xyrideen. Kongliga Svenska Vetenskaps-Akademiens Handlingar 24: $1-75$.

Phonsena, P.; Chantaranothai, P. \& Meesawat, A. 2012. Four new species of Xyris (Xyridaceae) from Thailand. Blumea 57: 116-124. 
Pires, J.M. \& Prance, G.T. 1985. The vegetation types of Brazilian Amazon. In: Prance, G.T. \& Lovejoy, T.E. (eds.). Amazonia. Key Environments Series. Pergamon Press, Oxford. Pp.109-145.

Prance, G.T. 1975. Estudo sobre a vegetação das campinas Amazônicas: I. Acta Amazônica 5: $207-$ 209.

Rossetti, D.F.; Bertani, T.C.; Zani, H.; Cremon, E.H. \& Hayakawa, E.H. 2012a. Late Quaternary sedimentary dynamics in Western Amazonia: implications for the origin of open vegetation/forest contrasts. Geomorphology 177-178: 74-92.

Rossetti, D.F.; Zani, H.; Cohen, M.L.C. \& Cremon, E.H. 2012b. A Late Pleistocene-Holocene wetland megefan in the Brazilian Amazonia. Journal of Sedimentary Geology 282: 276-293. [DOI: 10.1016/j.sedgeo.2012.09.015].

Rudall, P.J. \& Sajo, M.G. 1999. Systematic position of Xyris: flower and seed anatomy. International Journal of Plant Sciences 160: 795-808.

Santos, O.; Nelson, B. \& Giovannini, C.A. 1993. Corpos de areia sob leitos abandonados de grandes rios. Ciência Hoje 16: 22-25.

Silva, G.O. \& Wanderley, M.G.L. 2013. A família Xyridaceae no município de Mucugê, BA, Brasil. Hoehnea 40: 51-76.

Seubert, M. 1855. Xyrideae. In: Martius, C.F.P. \& Eichler, A.G. (eds.). Flora brasiliensis. Frid. Fleischer, Leipzig.Vol. 3, pars 1, pp. 209-224.

Smith, L.B. \& Downs, R.J. 1954. Xyridaceae from Brazil. Journal of the Washington Academy of Sciences 44: 311-314.

Smith, L.B. \& Downs, R.J. 1958. The Machris Brazilian Expedition. Contributions in Science 32: 13-15.

Smith, L.B. \& Downs, R.J. 1960. Xyridaceae from Brazil II. Proceedings of the Biological Society of Washington 73: 245-260.

Smith, L.B. \& Downs, R.J. 1965. Xyridáceas. In: Reitz, P.R. (ed.). Flora Ilustrada Catarinense. Herbário Barbosa Rodrigues, Itajaí, Parte 1, XIRI: 1-53.

Smith, L.B. \& Downs, R.J. 1968. Xyridaceae. In: Hoehne, F.C. (ed.; con't. A. R. Teixeira). Flora Brasílica. Instituto de Botânica, São Paulo 9: 1-125.

Soltis, D.E.; Soltis, P.S.; Chase, M.W.; Mort, M.E.; Albach, D.C.; Zanis, M.; Savolainen, V.; Hans, W.H.; Hoot, S.B.; Fay, M.F.; Axtell, M.; Swensen, S.M.; Prince, L.M.; Kress, W.J.; Nixon, K.C. \& Farris, J.S. 2000. Angiosperm phylogeny inferred from $18 \mathrm{~S}$ rDNA, $r b c L$, and $a t p B$ sequences. Journal of the Linnean Society 133: 381-461.
Steudel, E.G. 1855. Synopsis Plantarum Glumacearum - Pars II. Cyperaceae et familiae affinis, Restiaceae, Eriocaulaceae, Xyrideae, Desvauxieae, Junceae. J.B. Metzler. Royal, Stuttgart. 348p.

Steyermark, J.A. 1984. Flora of the Venezuelan Guayana - Part I. Annals of the Missouri Botanical Garden 71: 297-340.

Thiers, B. [continuously updated]. Index Herbariorum: A global directory of public herbaria and associated staff. New York Botanical Garden's Virtual Herbarium. Available at <http://sweetgum.nybg. org/ih/>. Access on 31 December 2014.

Wanderley, M.G.L. 2003. Xyridaceae. In: Wanderley, M.G.L.; Shepherd, G.J.; Giulietti, A.M. \& Melhem, T.S. (eds.). Flora Fanerogâmica do Estado de São Paulo. Vol. 3. FAPESP: RiMa, São Paulo. Pp. 333-348.

Wanderley, M.G.L. 2010. Cinco novas espécies de Xyris (Xyridaceae) da Serra do Cipó, Minas Gerais, Brasil. Rodriguésia 61: 83-94.

Wanderley, M.G.L. 2011. Flora da Serra do Cipó, Minas Gerais: Xyridaceae. Boletim de Botânica da Universidade de São Paulo 29: 69-134.

Wanderley, M.G.L.; Mota, N.F.O.; Silva, G.O.; Guedes, J.S. \& Lozano, E.D. 2014. Xyridaceae. In: Lista de Espécies da Flora do Brasil. Jardim Botânico do Rio de Janeiro, Rio de Janeiro, Brazil. Available at $<$ http://floradobrasil.jbrj.gov.br/jabot/floradobrasil/ FB33383>. Access 25 November 2014.

Wanderley, M.G.L. \& Silva, M.B.C. 2009. Flora de Grão-Mogol, Minas Gerais: Xyridaceae. Boletim de Botânica da Universidade de São Paulo 27: 137-147.

Wanderley, M.G.L.; Silva, G.O.; Guedes, J.O.; Valente, A.S.M.; Fernandez, E.P.; Monteiro, N.P. \& Borges, R.A.X. 2013. Xyridaceae. In: Martinenelli, G. \& Moraes, M.A. (eds.). Livro vermelho da flora do Brasil. Andrea Jakobsson \& Instituto de Pesquisas Jardim Botânico do Rio de Janeiro, Rio de Janeiro. Pp. 1027-1036.

Zani, H.; Rossetti, D.F.; Cohen, M.L.C.; Pessenda, L.C.R. \& Cremon, E.H. 2012. Influence of landscape evolution on the distribution of floristic patterns in northern Amazonia revealed by $\delta^{13} \mathrm{C}$ data. Journal of Quaternary Science 27: 854-864.

Zani, H. \& Rossetti, D.F. 2012. Multitemporal Landsat data applied for deciphering a megafan in northern Amazonia. International Journal of Remote Sensing 33: 6060-6075.

Zona, S.; Davis, P.; Gunathilake, L.A.A.H.; Prince, J. \& Horn, J.W. 2012. Seeds of Eriocaulaceae of the Unitec States and Canada. Castanea 77: 37-45. 


\section{List of exsiccatae}

Amaral, M.C.E. 28 (2.9), 4 (2.14), 39 (2.15). Barbosa, T.D.M. 1233, 1257, 1305, 1322, 1337, 1369, 1434 (1.1), 1055, 1083,1084, 1211, 1332, 1430 (1.2), 1095 (1.3), 1313, 1325, 1342, 1346, 1366 (1.4), 1210, 1333 (2.4), 1070,1071, 1443 (2.6), 1442 (2.9), 1336 (2.11), 1217 (2.12), 1367 (2.13), 1053, 1163 , 1306 (2.14). Cabral, F.N. 173 (1.2), 93 (2.14). Calió, M.F. 226 (1.2). Carvalho, F.A. 938 (1.1), 1027, 1040 (1.2), 877 (2.3), 976, 1022 (2.4), 933 (2.9), 997, 1016 (2.14), 2, 1058 (2.17). Cavalcanti, D. 200 (1.3). Conceição, A.N. 6 (2.4). Costa S.M. 758, 822 (1.2), 921 (1.4), 741 (2.3), 725, 997 (2.8), 784 (2.11), 753 (2.15). Costa, F.R.C. 1189, 1547, 1698 (1.2), 1678, 1530 (2.10), 1527, 1642, 1672, 1677 (2.14). Costa, S.M. 703, 928, 999 (1.1), 705, 723, 923, 929, 992 (1.2), 998 (1.3), 704 (2.1), 884, 908 (2.6), 778 (2.8), 801 (2.9), 909 (2.10), 708, 757 (2.12), 798, 799 (2.13), 812, $814(2.14), 800$ (2.16), 730, 782,796 (2.17). Curty, C.B. 10 (2.2), 8 (2.10). Ferreira, C.A.C. 9252, 12420 (1.2). Lins, J. 36 (1.2). Lourenço, A.R. 361 (1.2). Melo, A. 406 (1.3), 917 (2.16). Mota, N.F.O. 2343, 2406 (1.1), 1223, 1227, 2304, 2319, 2423 (1.2), 2325 (1.3), 2322 (1.4), 1229, 2316, 2377, 2405 (2.1), 2344 (2.2), 2303, 2305, 24302341 (2.3), 2299, 2313, 2397 (2.4), 1226, 2318 (2.5), 2307, 2429, 2311 (2.6), 2298, 2416 (2.7), 2310 (2.8), 1235, 2312, 2320, 2400 (2.9), 2422 (2.10), 1228, $12332302,2340(2.11), 2315,2339,2378,2398(2.12), 1230,1232,2326$, 2399, 2438 (2.13), 1234, 1237, 2300, 23142323 2383, 2401 (2.14), 2327 (2.15), 1224, 1231, 2306, 240224332440 (2.16), 1225, 2308, 2324, 2434, 2436 (2.17). Pedrollo, C.T. 143 (1.2), 125 (2.6). Pereira, P.A. 110 (1.2), 112 (2.2), 113 (2.10). Pessoa, E. 648 (1.2), 327 (2.4), 736 (2.12), 737 (2.14). Shimizu, G.H. 563 (2.3). Silva, G.O. 98 (1.1), 93 (1.2), 92 (2.3), 95 (2.9), 96 (2.13), 97 (2.12), 94 (2.14). Steward, W.C. 75 (2.5). Vicentini, A. 1460 (1.4). Zartman, C.E. 8522 (2.13). 